\title{
Araştırma Makalesi / Research Article \\ Karlı Dağlık Bir Havzada Günlük ve Aylık Akım Değerlerinin SWAT Modeliyle Değerlendirilmesi: Bitlis Çayı Havzası Örneği
}

\author{
Emrah YALÇIN ${ }^{1}$ \\ ${ }^{1}$ Kırşehir Ahi Evran Üniversitesi, Mühendislik-Mimarlık Fakültesi, Inşaat Mühendisliği Bölümü, Kırşehir. \\ e-posta: emrah.yalcin@ahievran.edu.tr ORCID ID: https://orcid.org/0000-0002-3742-8866
}

Anahtar kelimeler Hidrolojik model; SWAT; SWAT-CUP; Günlük ve aylık akım; Kar erimesi; Bitlis Çayı

Öz

Bu çalışmada, yerel meteoroloji istasyonlarının günlük meteorolojik ölçümleri ile kaba ölçekli topoğrafya, arazi örtüsü ve toprak verileri kullanılarak oluşturulan bir SWAT modelinin, karlı dağlık bir havzada günlük ve aylık akım değerlerini simülasyon ve tahmin performansı Bitlis Çayı örneğinde değerlendirilmiştir. Fırat-Dicle havzasında yer alan Bitlis Çayı́nın Baykan akım gözlem istasyonu yerindeki akım değerlerini simüle edebilmek için geliştirilen SWAT modeli, Baykan istasyonunun ölçüm verileri kullanılarak günlük ve aylık akım simülasyonları için ayrı ayrı kalibre edilip doğrulanmıştır. Hem kalibrasyon hem de doğrulama periyodunda günlük akım değerleri için iyi, aylık akım değerleri için ise çok iyi olarak nitelendirilebilecek simülasyon istatistikleri elde edilmiştir. Geliştirilen modelin, akım ölçümleri olmadan sadece meteorolojik veriler kullanılarak günlük ve aylık akımları ne derece doğru tahmin edilebileceği incelendiğinde ise modelin hem istatistiksel değerlendirme indeksleri hem de akımsüreklilik ilişkileri bağlamında tatmin edici tahmin performansları sunabildiği görülmüştür. Günlük akım tahminleri ile ölçüm verileri arasında yıllık maksimum zaman serileri bağlamında güçlü bir korelasyon elde edilememiş olsa da bu durumun hesaplanan tekerrürlü taşkın debileri bağlamında belirgin farklar yaratmadığı tespit edilmiştir. Elde edilen sonuçlar, geliştirilen SWAT modelinin, gelecek on yıllarda Bitlis Çayı'nın akım rejiminde meydana gelebilecek olası değişimlerin günlük ve aylık bazda incelenebilmesine olanak sağlayabileceğini göstermektedir.

\section{Evaluation of Daily and Monthly Streamflow Rates in a Snowy Mountainous Watershed with SWAT Model: A Case of Bitlis Creek Basin}

\section{Keywords}

Hydrologic model; SWAT; SWAT-CUP;

Daily and monthly streamflow; Snowmelt; Bitlis Creek

\begin{abstract}
In this study, the performance of a SWAT model constructed with daily weather observations of regional meteorological stations and coarse-scale topography, land cover, and soil data in simulating and forecasting daily and monthly streamflow rates in a snowy mountainous watershed is assessed with the example of Bitlis Creek. The SWAT model developed to simulate the flow rates of Bitlis Creek, located in the Euphrates-Tigris Basin, at the location of the Baykan stream-gauging station is calibrated and validated separately for daily and monthly flow simulations by using the records of the Baykan station. Simulation statistics that can be judged as good for daily flow rates and very good for monthly flow rates are obtained in both of the calibration and validation periods. When it is examined how accurately the developed model can predict the daily and monthly flows using only meteorological data without flow measurements, it is observed that the model can provide satisfactory forecast performances in the context of both statistical evaluation indices and flow-duration relations. Although a strong correlation between the daily flow estimates and observed data in terms of annual maximum time series cannot be obtained, it is observed that this situation does not result in significant differences in terms of the calculated recurrence flood peaks. The results indicate that the developed model can enable the investigations of possible changes in the flow regime of Bitlis Creek in the coming decades on daily and monthly time bases.
\end{abstract}

(C) Afyon Kocatepe Üniversitesi 


\section{Giriş}

Atmosferde giderek yoğunlaşan sera gazı konsantrasyonları sebebiyle küresel iklim koşullarında meydana gelmesi beklenen değişimlerin, dünyanın birçok yerinde sıcaklık ve yağış paternlerinin büyüklük ve mevsimsel varyasyonunu temelden değiştireceği yaygın olarak kabul edilmektedir (IPCC 2013). Bu değişimlerin akarsu rejimlerinde meydana getirebileceği olası değişiklikler, genellikle tarihsel veriler kullanılarak hazırlanan havza yönetim planlarında tarımsal üretim, içme ve kullanma suyu temini, enerji üretimi gibi amaçlar için öngörülen su arzlarının sağlanamaması intimalini doğurmaktadır (Daggupati et al. 2017, IPCC 2014). Özellikle kar birikimi ve erime süreçlerinde meydana gelebilecek değişikliklerin, kar yağışından beslenen dağlık havzalarda yer alan barajlarla karşılanacak su ihtiyaçlarının teminindeki kırılganlığı daha da arttıracağı öngörülmektedir (Adam et al. 2009). Ayrıca, değişen iklim koşullarının, kuraklık ve seller gibi aşırı olayların şiddeti ve sıklığını da etkileyerek havza depolama gereksinimleri ile baraj işletme politikalarının yeniden değerlendirilmesi hususlarında önemli sonuçlar doğurması muhtemeldir (Katz and Brown 1992). Bu nedenlerle, havza yönetim planlarının, geçmiş akım ölçümlerine değil, olası iklim değişikliği senaryoları için üretilen iklim projeksiyonları bazında elde edilen günlük ve/veya aylık akım tahminlerine göre hazırlanması, olası su arzı kırılganlıklarını minimize etmek için büyük önem arz etmektedir.

Hidrolojik modelleme, havzalarda hidrolojik döngü etkileşimlerini araştırmak için yaygın olarak kullanılan bir araçtır. Hidrolojik modeller, havza su dengesini düzenleyen toprak tipi, arazi kullanımı, iklim ve havza morfolojisi gibi faktörler ile hidrolojik bileşenler arasındaki ilişkinin kurularak, saha deneyleri ve doğrudan ölçümler yoluyla irdelenmesi mümkün olmayan geçmiş, mevcut ve gelecek dönemlere dair doğal ve yönetimsel kaynaklı çevresel değişimlerin etkilerinin değerlendirilmesini mümkün kılar (Rahaman et al. 2019). Son yıllarda uzaktan algılama ve coğrafi bilgi sistemleri teknolojilerinin devreye girmesiyle birlikte yüksek çözünürlüklü sayısal yükseklik modelleri, uydu görüntüleri, radar verileri gibi mekansal veri tabanlarıyla da desteklenen algoritmaların da geliştirilmesiyle, kullanılan zamansal ve mekansal ölçekler, farklı süreçlerin sunumu ve kullanılan denklemlere çözüm yöntemleri temelinde kategorize edilebilecek çok sayıda hidrolojik model geçiştirilmiştir (Himanshu et al. 2013, Pandey et al. 2016, Singh 1995). Arnold vd. (1998) tarafından geliştirilen Soil and Water Assessment Tool (SWAT) modeli, nehir havzalarının hidrolojik modelleme çalışmaları için çokça tercih edilen modellerden biridir (Douglas-Mankin et al. 2010, Gassman et al. 2007).

SWAT, çeşitli çevresel koşullara sahip farklı ölçeklerdeki havzalarda su miktarı, sedimantasyon ve su kalitesi konularını incelemek için yararlı bir araç olduğu kanıtlanmış, model parametrelendirmesini ve kalibrasyonunu zorlaştıran çok sayıda giriş parametresi gerektiren, sürekli zamanlı, yarı dağılımlı ve süreç bazlı bir simülasyon modelidir (Arnold et al. 2012). Nihai hedefleri ne olursa olsun, tarihsel akım ve meteorolojik gözlem verileri kullanılarak hedeflenen havzanın akım değerleri bazında hidrolojik dengesinin kurulması tüm SWAT uygulamaları için ilk temel adımdır (Yang et al. 2016). Kar erimesi/birikimi hidrolojisi, akımların ağırlıklı olarak kar erimesi kaynaklı oluştuğu havzalarda önemli bir bileşendir (Abbas et al. 2019, Liu et al. 2020). SWAT, her bir alt havza için on adete kadar tanımlanabilen yükseklik bantları ile bunlara ilişkin sıcaklık ve yağış değişim oranlarının belirlenerek, karla ilgili süreçlerin mekansal ve mevsimsel olarak değerlendirilebildiği bir kar modülü içermektedir (Fontaine et al. 2002, Luo et al. 2012, Pradhanang et al. 2011, Rahman et al. 2013).

SWAT uygulamalarının büyük çoğunluğu yağmurakım ilişkisinin baskın olduğu havzalarda gerçekleştirilmiştir (Douglas-Mankin et al. 2010, Gassman et al. 2007). Karla kaplı havzalar için gerçekleştirilen uygulamalar ise sınırlı olup, özellikle ilkbahar akımlarının ağırlıklı olarak kar erimesi kaynaklı olduğu dağlık havzalar için SWAT 
model performansı hakkında çok az şey bilinmektedir (Ahl et al. 2008, Grusson et al. 2015, Liu et al. 2020, Omani et al. 2017, Stratton et al. 2009, Troin and Caya 2014). Dağlık bir havzada kar erimesi-akım modellemesi, simülasyonun karmaşıklığı nedeniyle zor olarak görülmektedir (Abbas et al. 2019). Troin ve Caya (2014), başarısız performansların nedeninin, SWAT'ın yaz ve kış akımlarını uzlaştırmadaki zorluklarından kaynaklanabileceğini belirtmiştir. Stratton vd. (2009) ise daha iyi bir modelleme için toprak (örneğin; mevcut su içeriği ve doymuş hidrolik iletkenlik), kar (örneğin; değişim oranları ve erime) ve vejetasyon (örneğin; yaprak alan indeksi, maksimum kaplama indeksi) ile ilgili model parametreleri için saha ölçümlerinin öneminden bahsetmiştir.

Gassman vd. (2007), SWAT modeli kullanılarak gerçekleştirilen 115 akım simülasyonu çalışmasını kapsamlı bir şekilde gözden geçirmiş ve bu çalışmaların bazılarında elde edilen başarısız simülasyon sonuçlarının; model kurulumunda düşük çözünürlüğe sahip mekansal verilerin kullanılması, kullanılan meteoroloji istasyonlarının mekansal dağılımının doğru yapılmaması, tarihsel akım ölçümlerindeki hatalar, model kalibrasyonunun yapılmaması ile nispeten kısa kalibrasyon ve doğrulama periyotları kaynaklı olduğu sonucuna varmıştır. Ayrıca, aylık ve yıllık zaman ölçütlerinde yapılan akım simülasyonlarında elde edilebilen başarının günlük akım simülasyonlarında çoğu zaman elde edilemediği belirtilmektedir (Gassman et al. 2007, 2014). SWAT modeli kurulumu için gerekli mekansal veri setleri; sayısal yükseklik modeli, arazi kullanım/arazi örtüsü haritası ile toprak haritası olup, model sonuçlarının mekansal veri kalitesine olan yüksek hassasiyeti bilinmektedir (Al-Khafaji and Saeed 2018, Geza and McCray 2008, Tan et al. 2018). Bu noktada, eğer model kalibrasyonu ve doğrulaması için yeterli akım gözlem verisi mevcut ise model kurulumda temini için çok fazla zaman, çaba ve bütçe gerektiren saha ölçüm ve analizleri baz alınarak hazırlanmış yerel mekansal veri setleri yerine küresel kapsamlı açık erişim veri tabanlarından elde edilen düşük çözünürlüklü veri setleri kullanılarak, model kalibrasyonu ile bu veri setlerinin yarattığı belirsizliğin azaltılıp azaltılamayacağı sorusu, özellikle hidrolojik model kurulumunda mekansal veri eksikliğinin önemli bir sınırlayıcı faktör olmaya devam ettiği bölgeler için büyük önem arz etmektedir (Sharifi and Kalin 2010).

$\mathrm{Bu}$ çalışmada, kurulumunda yerel meteoroloji istasyonu ölçümleri ile küresel kapsamlı açık erişim veri tabanlarından elde edilen düşük çözünürlüklü mekansal veri setleri kullanılan bir SWAT modelinin yoğun kar yağışı ve birikimi gözlenen dağıık bir havzada günlük ve aylık akım değerlerini simülasyon ve tahmin performansı, Dicle Nehri'nin ana kollarından biri olan Bitlis Çayı örneğinde değerlendirilmiştir. İklim değişikliği etkileriyle yüzyıl sonuna kadar yıllık toplam akım miktarlarında \%25 ila \%55 arasında bir azalma potansiyeline sahip olan bir havzada yer alan Bitlis Çayı üzerinde, Baykan akım gözlem istasyonu (AGi) tarihsel akım ölçümleri kullanılarak planlanan beş hidroelektrik santral (HES) projesi bulunmaktadır (Bozkurt and Sen 2013, Int Kyn. 1). Uzun yıllar Bitlis Çayı akımlarının ölçüldüğü Baykan istasyonu havzası için geliştirilen SWAT modeli, AGI ölçüm verileri kullanılarak günlük ve aylık akım değerleri için ayrı ayrı kalibre edilip doğrulanmış ve model simülasyon performansları, AGi verileri baz alınarak belirlenen en iyi simülasyon sonuçlarına göre istatistiksel değerlendirme indeksleri çerçevesinde değerlendirilmiştir. AGi ölçümleri olmadan yalnızca meteorolojik veriler kullanılarak gerçekleştirilebilecek model simülasyonlarının akım tahmin performansları, kalibrasyon süreçleri sonunda elde edilen kalibre parametre değer aralıkları ve bu değer aralıklarında en iyi simülasyonu veren parametre değer setlerinin kullanılabilirliği irdelenerek değerlendirilmiştir. Bu kapsamda iki farklı yaklaşımla belirlenen günlük ve aylık akım tahminleri hem istatistiksel değerlendirme indeksleri hem de akım-süreklilik ilişkileri ile yıllık maksimum değer serileri bağlamında değerlendirilerek, bu tahminlerin havza HES projelerinin kurulu güç optimizasyonları ve güvenilir enerji hesaplamaları ile taşkın yapılarının boyutlandırılmasında kullanılıp kullanılamayacağı tartışılmıştır. 


\section{Materyal ve Metot}

\section{1. Çalışma alanı}

Bitlis Çayı havzası, Türkiye'nin doğusunda yer alan Bitlis ve Siirt il sınırları içerisinde takriben $41^{\circ} 36^{\prime}$ $42^{\circ} 15^{\prime}$ doğu boylamları ile $37^{\circ} 54^{\prime}-38^{\circ} 30^{\prime}$ kuzey enlemleri arasında konumlanmaktadır. Garzan, Botan ve Batman çaylarıyla birlikte Dicle Nehri'nin Türkiye sınırları içerisindeki dört ana kolundan biri olan Bitlis Çayı, Bitlis il merkezi civarında, takriben 1500 m kotlarında, bir ırmak karakteri kazanarak büyük bir eğimle güneye doğru akar ve $500 \mathrm{~m}$ kotlarında Kezer Çayı ile birleşerek 450 m kotlarında Botan Çayı'na karışır. Güneydoğu Toroslar sıradağ zinciri üzerinde yer alan Bitlis Çayı havzası, büyük bir kısmı 1500-2000 m yüksekliğinde ve genellikle volkanik ve kalker kayalardan teşekkül eden yaklaşık 1076 km²'lik bir yağış alanına sahiptir (EIE 1990). Bitlis Çayı üzerinde mevcut durumda işletme halinde herhangi bir hidroelektrik santral (HES) projesi bulunmamakla birlikte, Elektrik İşleri Etüt İdaresi Genel Müdürlüğü (EIE) ve tüzel kişiler tarafından geliştirilmiş olan toplam yaklaşık 143 MW kurulu güce sahip Deliktaş Regülatörü ve HES, Bitlis Regülatörü ve HES, Baykan Enerji Grubu (Baykan Barajı ve HES ile Baykan II Regülatörü ve HES) ile Başören Barajı ve HES projelerinin yapımı planlanmaktadır (Şekil 1) (EIE 1990, Yolsu 2009, İnt Kyn. 1).

Bitlis Çayı üzerinde iki adet AGi bulunmaktadır (Şekil 1). EiE tarafından işletilmiş olan $1145 \mathrm{~m}$ kotundaki E26A016 numaralı Karınca AGI'de sadece 1965-1970 yılları arasında akım gözlemleri yapılmıştır. $346,4 \mathrm{~km}^{2}$ 'lik yağış alanına sahip bu istasyon 1971 yılından bu yana kapalı durumdadır. Yine EiE tarafından işletilmiş olan $698 \mathrm{~m}$ kotundaki E26A010 numaralı Baykan AGi'nin ise 1955-2011 tarihleri arasında kesintisiz akım gözlemleri mevcuttur (İnt Kyn. 2). EiE'nin kapatılması sonucu EIE tarafından işletilen AGi'lerin 2012 yılı itibariyle Devlet Su İşleri Genel Müdürlüğüne (DSi) devri sonrasında, $636,5 \mathrm{~km}^{2}$ lik yağış alanına sahip bu istasyonda akım gözlemleri DSi tarafından devam ettirilmektedir (İnt Kyn. 2). Bitlis Çayı üzerinde planlanan depolamalı (baraj) ve nehir tipi HES projelerinin istikşaf ve fizibilite çalışmalarında E26A010 numaralı Baykan AGI'nin akım verilerinden faydalanılmıştır (EIE 1990, Yolsu 2009).

Özellikle farklı iklim kuşaklarının kesiştiği bir noktada yer almasından dolayı mikro-klima özelliği gösteren Baykan AGi havzası, Türkiye'nin en fazla kar yağışı alan bölgelerinden biridir (Aydin and Işhik 2015). Havzanın kuzeyinde, özellikle Bitlis ili civarında, şiddetli karasal iklim hüküm sürmektedir. Meteoroloji Genel Müdürlüğü (MGM) tarafından işletilen 1573 m rakımlı 17207 numaralı Bitlis Meteoroloji Gözlem i̇stasyonu (MGi) verilerine göre; yıllık ortalama sıcaklık $9,4^{\circ} \mathrm{C}$, yıllık toplam yağış ortalaması $1206,2 \mathrm{~mm}$, yıllık karla örtülü gün sayısı ortalaması 115,9 gün ve aylık ortalama kar yükseklikleri $4,5 \mathrm{~cm}$ ila $87,3 \mathrm{~cm}$ arasında değişmekte olup, $5 \mathrm{~m}$ kalınlığa kadar ulaşabilen kar örtüsünün bahar aylarından itibaren kalkmaya başladığı görülmektedir (Aydın ve Yaylak 2016, EIE 1990, MGM 2018a). 696 m ila 2610 m arasında değişen ortalama 1619 m yükseltiye sahip Baykan AGi havzasının güney kesimlerini temsil edebilecek havza çevresindeki en yakın meteoroloji istasyonu olan yine MGM'ye ait 895 m rakımındaki 17210 numaralı Siirt MGi'de ise yıllık ortalama sıcaklık $16,2^{\circ} \mathrm{C}$, yıllık toplam yağış miktarı $719,9 \mathrm{~mm}$, yıllık karla örtülü gün sayısı ortalaması 29,1 gün ve aylık ortalama kar yükseklikleri 4,7-13,5 cm olarak ölçülmüştür (Şekil 1) (MGM 2018b).

\subsection{SWAT modelinin kurulumu}

SWAT modeli kurulumu için gerekli dört ana veri seti; sayısal yükseklik modeli, arazi kullanım/arazi örtüsü haritası, toprak haritası ve havza içi/yakınlarında bulunan temsili meteoroloji istasyonlarının günlük meteorolojik gözlemleridir. Havzanın topoğrafik karakteristikleri ile arazi kullanımı ve toprak tipleri hakkındaki verilerin temini, küresel kapsamlı açık erişim veri tabanlarından sağlanmıştır. 1 yay-saniye çözünürlüklü (yaklaşık $30 \mathrm{~m}$ ) sayısal arazi yükseklik verisi, küresel kapsamlı Shuttle Radar Topography Mission (SRTM) veri tabanından elde edilmiştir (Int Kyn. 3). Havza toprak özellikleri, 1:5 milyon ölçekli Digital Soil Map of the World (DSMW) versiyon 3.6 


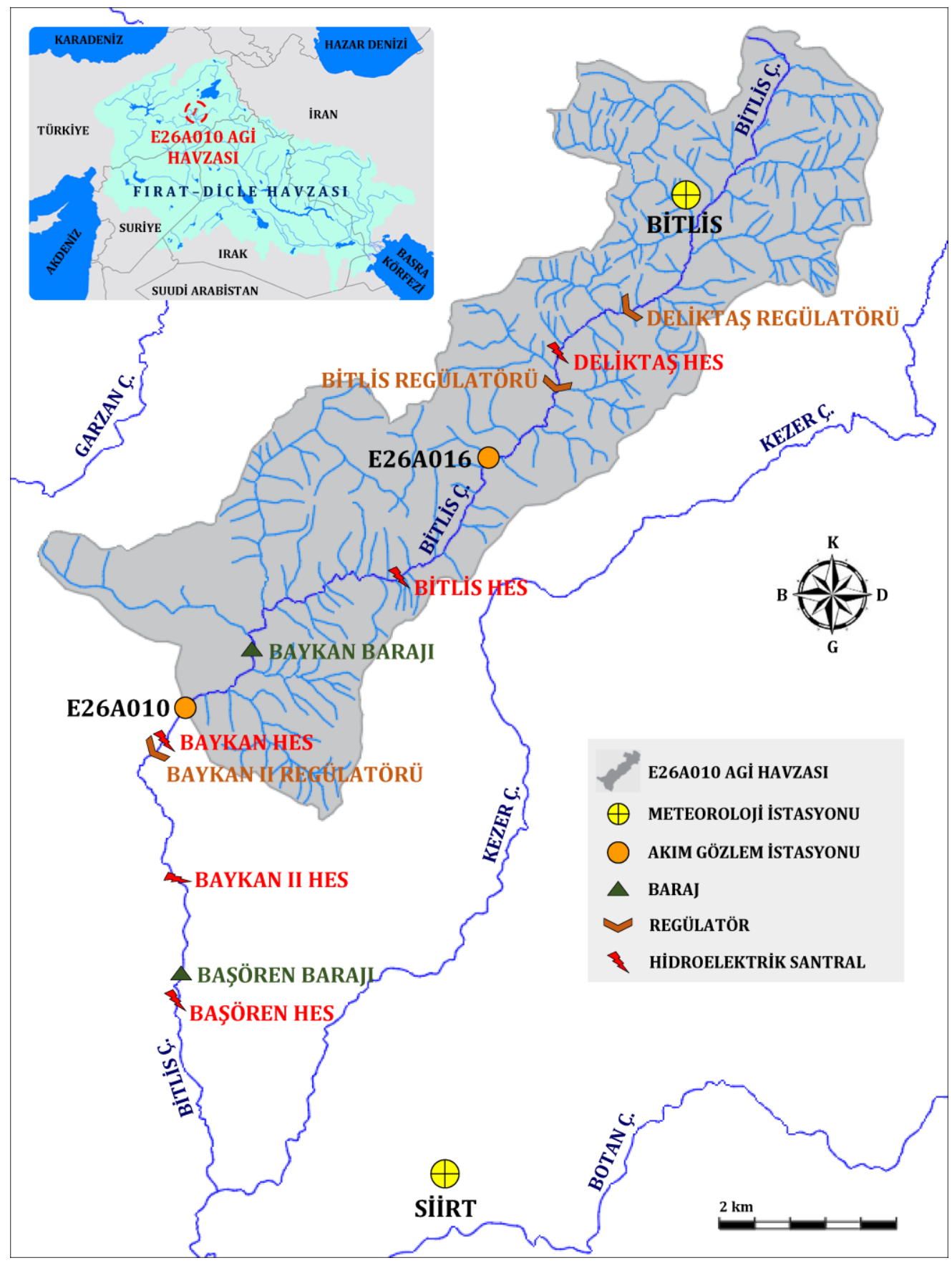

Şekil 1. Çalışma alanının konum haritası.

veri tabanından çekilmiştir (İnt Kyn. 4). Arazi kullanım/arazi örtüsü haritası, $1 \mathrm{~km}$ mekansal çözünürlüklü Global Land Cover (GLC2000) versiyon 2.0 veri tabanından elde edilmiş ve SWAT model girdi gereksinimlerine göre yeniden sınıflandırılmıştır (İnt Kyn. 5). Model yapımında ihtiyaç duyulan günlük meteorolojik gözlemler için ise Şekil 1'de havzaya göre konumları gösterilen Bitlis ve Siirt MGi'lerin ölçümlerinden faydalanılmıştır (MGM 2018c, MGM 2018d). Baykan AGI'nin 1955-2015 periyodunda 60 yıllık akım gözlemleri mevcut olsa da Bitlis ve Siirt
MGi'lerin söz konusu periyotta kesintisiz yağış $(\mathrm{mm})$, maksimum ve minimum hava sıcaklığı $\left({ }^{\circ} \mathrm{C}\right)$, güneş ışıması $\left(\mathrm{MJ} / \mathrm{m}^{2}\right)$, rüzgar $\mathrm{kızı}(\mathrm{m} / \mathrm{s})$ ve bağı nem ile ilgili günlük meteorolojik parametre kayıtları bulunmamaktadır. Buna göre, meteorolojik istasyon verilerinde en az kesintiye sahip en uzun periyot olan 1 Ocak 1984 - 31 Aralık 2009 dönemi, Baykan AGI yerinde doğal akış paterninin henüz bozulmamış olduğu Bitlis Çayı akımlarını günlük ve aylık bazda simüle etmek için geliştirilecek SWAT modelinin analiz periyodu olarak belirlenmiştir. 
SWAT modelinin kurulumu, SWAT havza tanımlama menüsüne girdi olarak sunulan sayısal yükseklik modeli verisi kullanılarak otomatik olarak gerçekleştirilen havza tanımlama işlemiyle başlamıştır (Şekil 2a). Bu aşamada, Baykan istasyonu havzası için 81 alt havza tanımlanmış ve bu alt havzalar için eğim değişimi, arazi eğim uzunluğu gibi alt havza parametreleri hesaplanmıştır (Şekil 2b). Model kurulumunun ikinci aşamasında, tanımlanan alt havzalar, SWAT hidrolojik etki birimi (HRU) analizi menüsünde otomatik olarak arazi kullanımı, toprak ve topoğrafik eğim karakteristiklerinin tekil kombinasyonlarına sahip HRU'lara bölünmüştür. Bu aşamada ilk olarak, kullanılan sayısal yükseklik modeli ile aynı projeksiyona sahip arazi kullanım/arazi örtüsü haritası grid formatında modele girdi olarak sunulmuş ve GLC2000 veri tabanında tanımlanan kategoriler, SWAT global veri tabanındaki aynı veya benzer birimlerin tanımlarına karşııık gelen altı arazi kullanım sınıfında yeniden tanımlanmıştır (Arnold et al. 2013). Bu sınıflar; çeşitli-çalı (RNGB), tarımsal arazi-genel (AGRL), orman-yaprak dökmeyen (FRSE), mera (PAST) ve çeşitli-çayır (RNGE) olup bu arazi kullanım sınıflarının havza alanı kaplama yüzdeleri sırasıyla $\% 62,65, \% 27,63, \% 5,26, \% 3,98$ ve \%0,48'dir (Şekil 2c). İinci olarak, DSMW veri tabanından çekilen grid bazlı toprak verisi, model veri tabanı dosyasına DSMW topraklarının özellikleri eklendikten sonra, sayısal yükseklik modeli ve arazi kullanım/arazi örtüsü verileriyle aynı projeksiyonda modele yüklenmiştir. Birleşmiş Milletler Gıda ve Tarım Örgütü (FAO) toprak sınıflandırma sistemine göre lithosol-ötrik cambisol (I-Be-c-3093), lithosolkalkerik regosol-kalsik xerosol (I-Rc-Xk-c-3122), kalsik kastanozem (Kk16-2b-3169) ve haplik xerosol (Xh31-3a-3288) olmak üzere dört farklı toprak tipinde sınıflandırılan model toprak katmanı Şekil $2 d^{\prime}$ de sunulmuştur (int Kyn. 6). Daha sonra, eğim ayrıştırma işlemi, Şekil 2e'de gösterildiği üzere beş eğim sınıfı göz önüne alınıp, çoklu eğim seçeneği kullanılarak uygulanmıştır. HRU yapılandırılmasında oluşabilecek küçük birimleri elimine edebilmek için arazi kullanımı, toprak ve eğim için sırasıyla \%5, \%5 ve $\% 15^{\prime}$ lik eşik değerler belirlenmiştir. Buna göre, tanımlanan 81 alt havza için toplam 586 HRU oluşturulmuştur.

Model kurulumunun üçüncü adımında, Bitlis ve Siirt meteoroloji istasyonlarının aylık meteorolojik gözlem istatistikleri ve coğrafi konumları (enlem, boylam ve yükselti bilgileri) model veri tabanı dosyasına eklenmiş ve istasyonların 1 Ocak 1984 31 Aralık 2009 dönemi günlük meteorolojik ölçüm verileri modele aktarılmıştır. Yarım saatlik yağış ve çiy noktası sıcaklığıyla ilgili olanlar haricindeki tüm aylık meteorolojik gözlem istatistikleri, WGNmaker4.1.xIsm Microsoft Excel makrosu kullanılarak hesaplanmıştır (İnt Kyn. 7). İstasyonların aylık maksimum yarım saatlik yağış değerleri, aylık maksimum günlük yağıs ölçümlerinin yarım saatlik plüvyograf katsayılarıyla çarpılmasıyla belirlenmiştir (MGM 2018e, MGM 2018f). Her ayın ortalama günlük çiy noktası sıcaklıkları ise istasyonların günlük maksimum ve minimum hava sıcaklıkları ile günlük ortalama yüzde bağıl nem verileri kullanılarak DOS tabanlı dew02.exe programıyla hesaplanmıştır (Int Kyn. 7). İstasyonların rüzgar hızı ve güneş ışıması verilerindeki boşluklar, modelin simülasyon sürecinde aylık meteorolojik gözlem istatistiklerini kullanarak atadığı temsili günlük değerlerle otomatik olarak doldurulacaktır.

SWAT modelinin proje veri tabanı dosyası vasıtasıyla model alt havzalarına yükseklik bantları eklenerek model kurulumu tamamlanmıştır. Bu işlemin amacı, modelin her bir alt havzadaki yüksekliğe bağı yağış ve sıcaklık değişimlerini hesaba katarak her bir yükseklik bandı için ayrı ayrı kar yağışı ve kar erimesini simüle edebilmesini sağlamaktır (Abbaspour et al. 2007). Bu kapsamda, her bir alt havzada minimum ve maksimum yükseltiler arasındaki farklar hesaplanmış ve yükselti farkının yağış ve sıcaklık üzerindeki orografik etkilerini dikkate almak için oldukça küçük olduğu alt havzalar hariç tüm alt havzalar için beş yükseklik bandı oluşturulmuştur (Pradhanang et al. 2011). Yükseklik bantlarının orta nokta yükseltileri (ELEVB) ile yükseklik bantları içindeki alt havza alan fraksiyonları (ELEVB_FR), DOS tabanlı Make_ELEV_BAND programı kullanılarak hesaplanmıştır (Abbaspour 2015). Yükseklik 
(a)

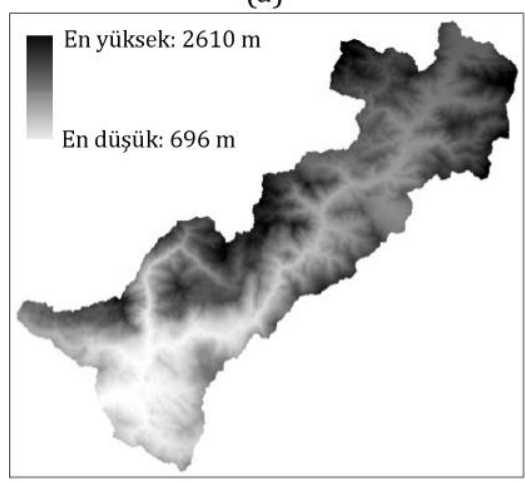

(b)

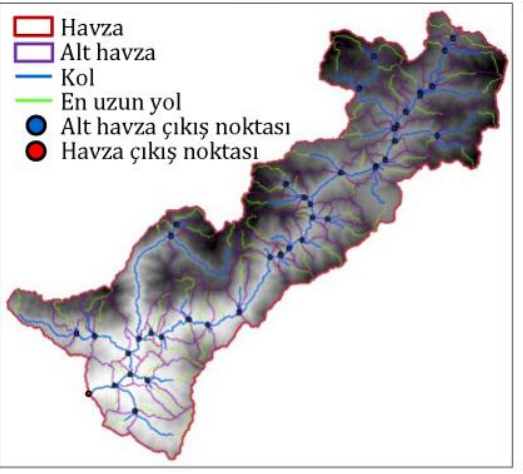

(c)

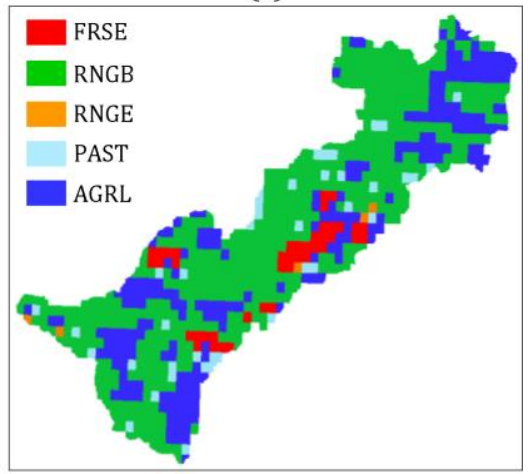

(d)

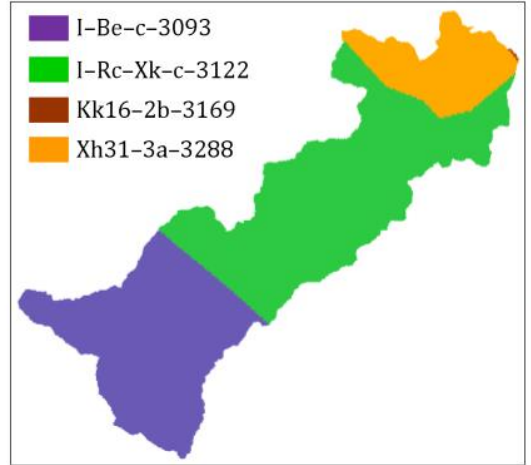

(e)

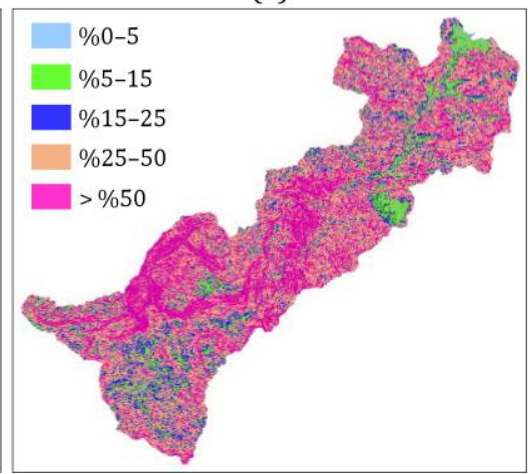

Şekil 2. Model kurulum aşamaları: (a) sayısal yükseklik modeli, (b) havza tasviri, (c) arazi kullanım sınıfları, (d) toprak sınıfları ve (e) eğim sınıfları.

bantlarında kar yağışı ve kar erimesini simüle edebilmek amacıyla sıcaklık değişim oranı (TLAPS) ve yağış değişim oranı (PLAPS) parametreleri için sırasıyla $-6{ }^{\circ} \mathrm{C} / \mathrm{km}$ ve $10 \mathrm{~mm} \mathrm{H}_{2} \mathrm{O} / \mathrm{km}$ değerleri varsayılmıştır. Model proje veri tabanı dosyasına alt havzalar için belirlenen ELEVB, ELEVB_FR, TLAPS ve PLAPS değerleri atanarak SWAT modelinin kurulumu tamamlanmıştır (Arnold et al. 2013).

Kurulan SWAT modeli için simülasyon periyodu 1 Ocak 1984 - 31 Aralık 2009 olarak ayarlanmıştır. Bu periyodunun ilk dört yılı istatistiklerin toplanmadığı model ısınma süresi olarak belirlenmiş ve çalışma havzası akım değerleri 22 yıllık bir periyotta (19882009) günlük ve aylık bazda ayrı ayrı simüle edilmiştir. Kurulan model, günlük ve aylık ortalama akım simülasyonları bazında ayrı ayrı kalibre edilip doğrulanacağı için, bundan sonra amacı doğrultusunda günlük model ve aylık model adları altında tanımlandırılacaktır.

\subsection{Günlük ve aylık SWAT modellerinin kalibrasyonu ve doğrulaması}

Günlük ve aylık modellerin kalibrasyon ve doğrulama analizleri SWAT Calibration and Uncertainty Procedures (SWAT-CUP) yazılımı kullanılarak yapılmıştır (Abbaspour 2015). Model kalibrasyonu, doğrulama, hassaslık ve belirsizlik analizleri için SWAT-CUP yazılım paketi içerisinde yer alan Sequential Uncertainty Fitting Version 2 (SUFI-2) algoritması seçilmiştir (Abbaspour 2015, Abbaspour et al. 2004). Model kalibrasyon sürecinde; girdi verileri, model parametreleri, teorik model ve ölçülen akım değerleriyle ilgili tüm belirsizlikler parametre değer aralıkları üzerine dağıtılarak, iteratif bir süreçle ölçülen akım verilerinin çoğunun modelin \%95 tahmin belirsizliği (95PPU) bandı içerisinde kalması ve aynı zamanda 95PPU bant kalınlığının da mümkün olduğunca ince olması amaçlanır. Bu noktada, uyum iyiliği $P$ faktörü ve $R$ faktörü ile değerlendirilmektedir (Abbaspour et al. 2004). $P$ faktörü, 95PPU bandı içerisinde yer alan ölçüm değerlerinin 0 ile 1 arasında değişen oranı olup, $R$ faktörü ise 95PPU bandının ortalama kalınlığının ölçüm değerlerinin standart sapmasına oranıdır. Daha büyük bir $P$ faktörü değeri sadece daha büyük bir $R$ faktörü değeri ile elde edilebildiğinden iki endeks arasında bir denge kurulmalıdır (Abbaspour et al. 2015). Bu bant 
aralığında elde edilen en iyi simülasyon performansını değerlendirmek için ise yaygın olarak belirleme katsayısı $\left(r^{2}\right)$ ve ölçüm verileri ile simülasyon sonuçlarının kesişimi sıfıra eşit olan lineer regresyon çizgisinin eğiminin $(b)$ çarpımı olan $b r^{2}$, Nash-Sutcliffe katsayısı (NSE), yüzde sapma (PBIAS) ve kök ortalama karesel hatanın ölçüm verisisin standart sapmasına oranı (RSR) istatistikleri kullanılmaktadır (Abbaspour et al. 2015, Moriasi et al. 2007).

Baykan AGi'de ölçülen günlük ve aylık akım değerleri ile onlara karşılık gelen simüle değerlerdeki farklııkların büyüklük ve dinamiklerini bir arada göz önüne alabilmek amacıyla, SUFI-2 optimizasyon prosedürünün hedef fonksiyonu olarak $b r^{2}$ seçilmiştir (Glavan and Pintar 2012). Günlük ve aylık modellerin kalibrasyonu için 19882001 periyodu, kalibre modellerin doğrulanması için ise 2002-2009 periyodu baz alınmıştır. Model kalibrasyonları, parametre etkileşimi ve tanımlanabilirlik sorunlarından kaçınmak amacıyla üç aşamada gerçekleştirilmiştir: (1) yağış ve sıcaklık değişim oranı parametrelerinin kalibrasyonu ve bu parametrelerin en iyi simülasyon değerlerine sabitlenerek kalibrasyon sürecinden çıkarılması, (2) hassas kar parametrelerinin kalibrasyonu ve bu parametrelerin en iyi simülasyon değerlerine sabitlenerek kalibrasyon sürecinden çıkarılması ve (3) model proje veri tabanının hidrolojik etki birimi seviyesi yeraltı suyu (.gw), toprak (.sol), hidrolojik etki birimi (.hru) ve yönetim (.mgt) girdi dosyaları ile alt havza seviyesi ana kanal (.rte) ve havza seviyesi havza (.bsn) girdi dosyalarında yer alan diğer hassas model parametrelerinin kalibrasyonu (Abbaspour et al. 2007, Abbaspour et al. 2015, Yalcin 2019).

Günlük ve aylık model kalibrasyon süreçlerinin her aşamasında, her bir parametrenin hassasiyeti, kısmen büyük ancak fiziksel olarak makul bir parametre belirsizlik aralığında, diğer tüm parametreler varsayılan değerlerinde sabit tutularak değerlendirilmiştir. Her bir parametrenin tekil hassasiyet analizi için, atanan parametre değer aralığında Latin hiperküp örnekleme yoluyla elde edilen 50 simülasyondan oluşan tek bir iterasyon yapılmıştır. Daha sonra, bu analizlerle tanımlanan hassas parametreler ve belirlenen başlangıç değer aralıklarına göre, 500 simülasyondan oluşan birleşik bir iterasyon gerçekleştirilmiştir. Program, mevcut iterasyonda en büyük hedef fonksiyon değerini veren en iyi simülasyona ait parametre değer setine odaklanarak sonraki iterasyon için yeni parametre değer aralıkları önermektedir. Önerilen parametre değer aralıkları, SWAT yazııımı mutlak parametre değer aralıklarına ve daha önce yapılmış hassaslık analizlerine göre yeniden ayarladıktan sonra ikinci birleşik iterasyon gerçekleştirilmiştir. Birleşik iterasyonlar, elde edilen akım değerlerinde hem $P$ faktörü ve $R$ faktörü değerleri hem de hedef fonksiyon $b r^{2}$, NSE, PBIAS ve RSR istatistikleri açısından daha fazla iyileşme sağlanamayana kadar devam ettirilmiştir. Buna göre, son iterasyon ilgili parametreler için en iyi değer aralıklarına, bu iterasyonun en yüksek hedef fonksiyon değerini veren simülasyonu ise en iyi parametre değer setine sahiptir (Abbaspour et al. 2007, Abbaspour et al. 2015).

1988-2001 periyodunda günlük ve aylık model kalibrasyonları yapıldıktan sonra, modeller, 20022009 periyodunda kalibre parametre değer aralıklarında 500 simülasyondan oluşan birer birleşik iterasyonla çalıştırılarak Baykan AGi'de ölçülen tarihsel günlük ve aylık ortalama akım değerlerine karşı doğrulanmıştır. Doğrulama periyodu model performansları yine $P$ faktörü, $R$ faktörü, $b r^{2}$, NSE, PBIAS ve RSR istatistikleri açısından değerlendirilmiştir. Doğrulama periyodu için elde edilen en iyi simülasyon sonuçları, gerçekleştirilen birleşik iterasyonda AGi ölçüm verilerine göre en yüksek hedef fonksiyon değerini veren simülasyona aittir. Bu sonuçların, akım verileri olmaması durumunda yalnızca meteorolojik veriler kullanılarak (örneğin, iklim değişikliğinin akım rejimine etkileri analiz edilirken) yapılacak günlük ve aylık model simülasyonlarının akım tahmin performanslarını değerlendirmek için kullanılması gerçekçi olmayacaktır. Bu sebeple, günlük ve aylık modellerin $A G i$ verileri kullanılmadan doğrulama periyodu akım tahmin performanslarını değerlendirebilmek için (1) kalibre model en iyi simülasyon parametre değer seti 
kullanılarak yapılan tek bir simülasyonla elde edilen tahminler (en iyi simülasyon tahminleri) ve (2) kalibre parametre değer aralıkları için tek bir birleşik iterasyonla elde edilen simülasyon sonuçlarının kümülatif dağılımının $\% 2,5$ ve $\% 97,5$ seviyelerinde belirlenen 95PPU bandının \%50 belirsizlik seviyesi (medyan) değerleri (M95PPU) baz alınmıştır (Lemann et al. 2017, Yalcin 2019). Böylece, hem kalibrasyon periyodu en iyi parametre değer seti hem de kalibre parametre değer aralıklarının kullanılabilirlikleri doğrulama periyodunda ayrı ayrı değerlendirilerek günlük ve aylık modellerin akım tahmin performansları irdelenebilmiştir. Bu kapsamda iki farklı yöntemle belirlenen doğrulama periyodu günlük ve aylık akım tahminleri ile Baykan istasyonu günlük ve aylık ortalama akım değerlerinin uyumu $b r^{2}$, NSE, PBIAS ve RSR istatistikleri açısından değerlendirilmiştir.

\section{Bulgular ve Tartışma}

\subsection{Kalibrasyon ve doğrulama sonuçları}

Akım simülasyonuna yönelik model kalibrasyonu ve kalibre modelin doğrulanması için, model ölçeği ile model kurulumu ve kalibre edilmesinde kullanılan verilerin kalitesine bağlı olarak 0,7 'den büyük bir $P$ faktörü değeri ve 1,5'in altında (1 civarı) bir $R$ faktörü değeri yeterli görülmektedir (Abbaspour 2015). Elde edilen 95PPU bandının en iyi simülasyonu bazında modelin yeterli olarak değerlendirilebilmesi için ise $b r^{2}$ değerinin 0,60'tan büyük olması gerekmektedir (Santhi et al. 2001, Van Liew et al. 2007). Ayrıca, Moriasi vd. (2007), 0,75 ile 1,00 arasında bir NSE, $\pm \% 10$ 'dan düşük bir PBIAS ve 0,50'den küçük bir RSR değerinin, model performansının aylık zaman ölçeğinde elde edilen akım değerleri bazında oldukça iyi olduğunu söylemek için yeterli olduğunu belirtmiştir. Genel olarak, aylık akım değerleri için 0,50'den daha yüksek bir NSE, $\pm \% 25$ 'in altında bir PBIAS ve 0,70'ten küçük bir RSR değeri elde edildiğinde, model performansı tatmin edici olarak değerlendirilmektedir (Moriasi et al. 2007). Literatürde, günlük akım simülasyonları açısından model performansının söz konusu istatistikler doğrultusunda değerlendirilebileceği genel olarak kabul görmüş bir kriter bulunmadığı ve günlük model performansının aylık model performansına göre genellikle daha düşük kaldığı göz önüne alınarak, günlük akım simülasyon istatistikleri için de aylık zaman ölçeğinde yapılan simülasyonlar için kullanılan kriterlerin kullanılması uygun görülebilir (Gassman et al. 2007, Shrestha et al. 2018, Yang et al. 2016).

Açık erişim veri tabanlarından elde edilen kaba ölçekli sayısal yükseklik modeli, arazi kullanım/arazi örtüsü ve toprak verileri ile çalışma havzası içerisi ve yakınlarındaki iki meteoroloji istasyonunun günlük meteorolojik gözlemleri kullanılarak oluşturulan SWAT modeli, Baykan istasyonunun 1988-2001 periyodu günlük ve aylık akımlarını sırasıyla 0,59 ve 0,84 $b r^{2}$ değerleri ile simüle etmiştir. Günlük bazda gerçekleştirilen model simülasyonunun ana problemi, Şekil $3 a^{\prime} d a$ görüldüğü üzere, tüm simülasyon periyodu süresince pik akım değerlerinin ölçülenlerden daha yüksek simüle edilmesidir. Ayrıca, elde edilen 0,34'lük NSE ve 0,81'lik RSR değerleri, SWAT modelinin kalibrasyon öncesinde Baykan istasyonu günlük akım değerlerini simüle etmede güvenilir bir araç olarak kullanılabilmesi için istatistiksel olarak yeterli olmadığını göstermektedir (Moriasi et al. 2007). Aylık bazda yapılan model simülasyonu ise her ne kadar istatistiksel olarak iyi bir performans sergilese de ana problem, Şekil 4a'da görüldüğü üzere, simülasyon süresince düşük akım değerlerinin sistematik olarak ölçülenlerden daha düşük simüle edilmesidir. $\mathrm{Bu}$ problemler, geliştirilen SWAT modelinin, SWAT-CUP yazııımında manuel olarak günlük ve aylık zaman ölçütlerinde ayrı ayrı üçer aşamada kalibre edilmesiyle çözülmeye çalışılmıştır.

Günlük model kalibrasyon sürecinin ilk adımında, hedef fonksiyon $b r^{2}$ değeri, TLAPS ve PLAPS parametrelerinin kalibre edilip sabitlenmesiyle 0,60'a yükselmiştir. Bir sonraki adımda, gerçekleştirilen tekil hassasiyet analizleri sonucunda belirlenen altı kar parametresinin en iyi simülasyon parametre değerlerine sabitlenmesi $b r^{2}$ değerini 0,65 'e yükseltmiştir. Bu altı parametreden 
(a)

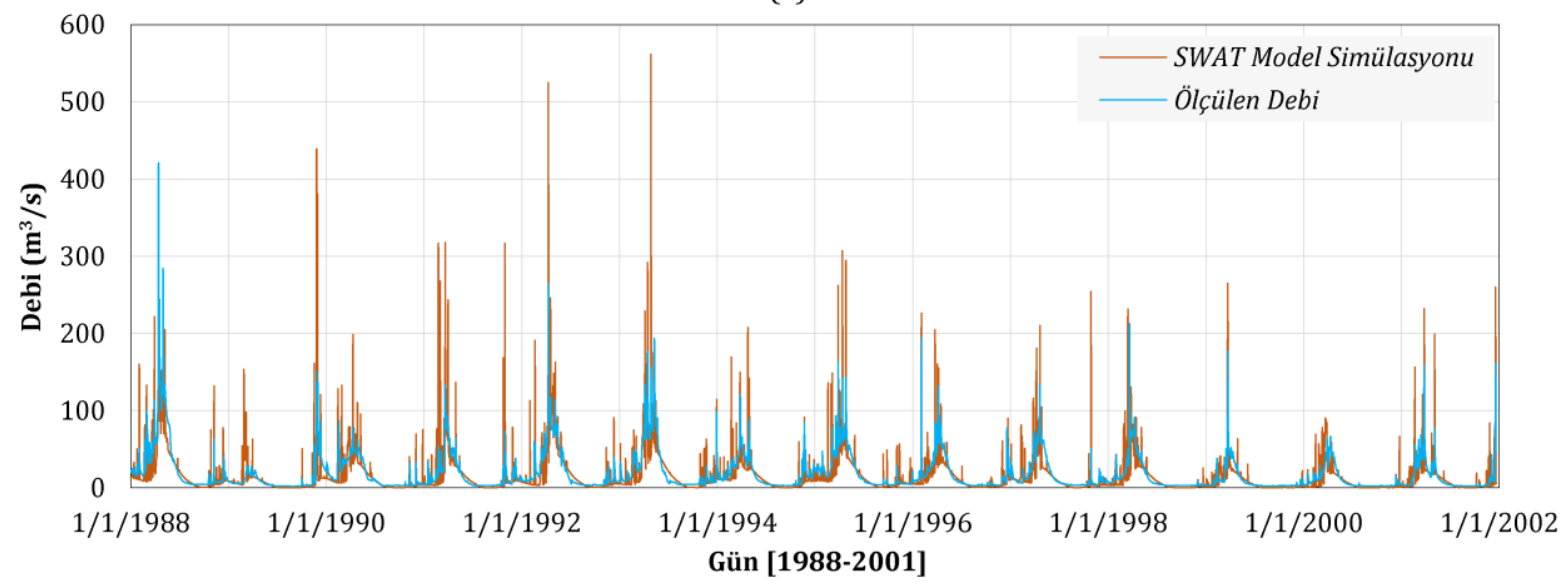

(b)

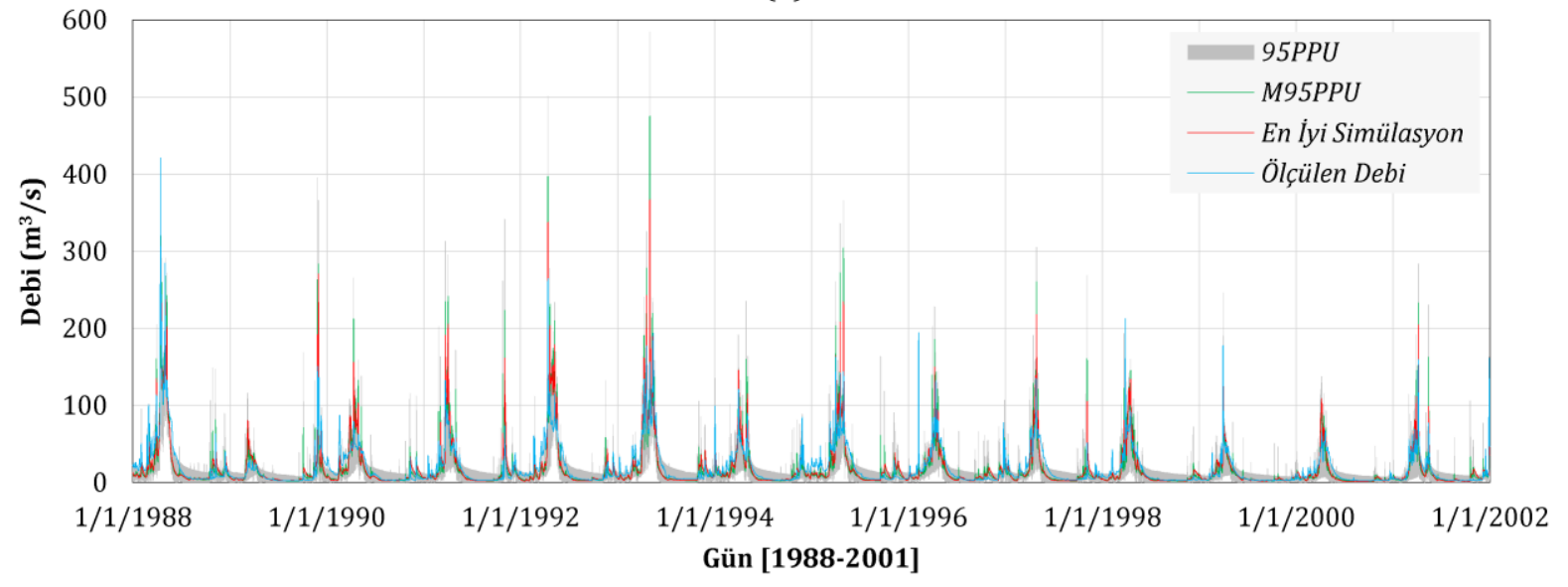

(c)

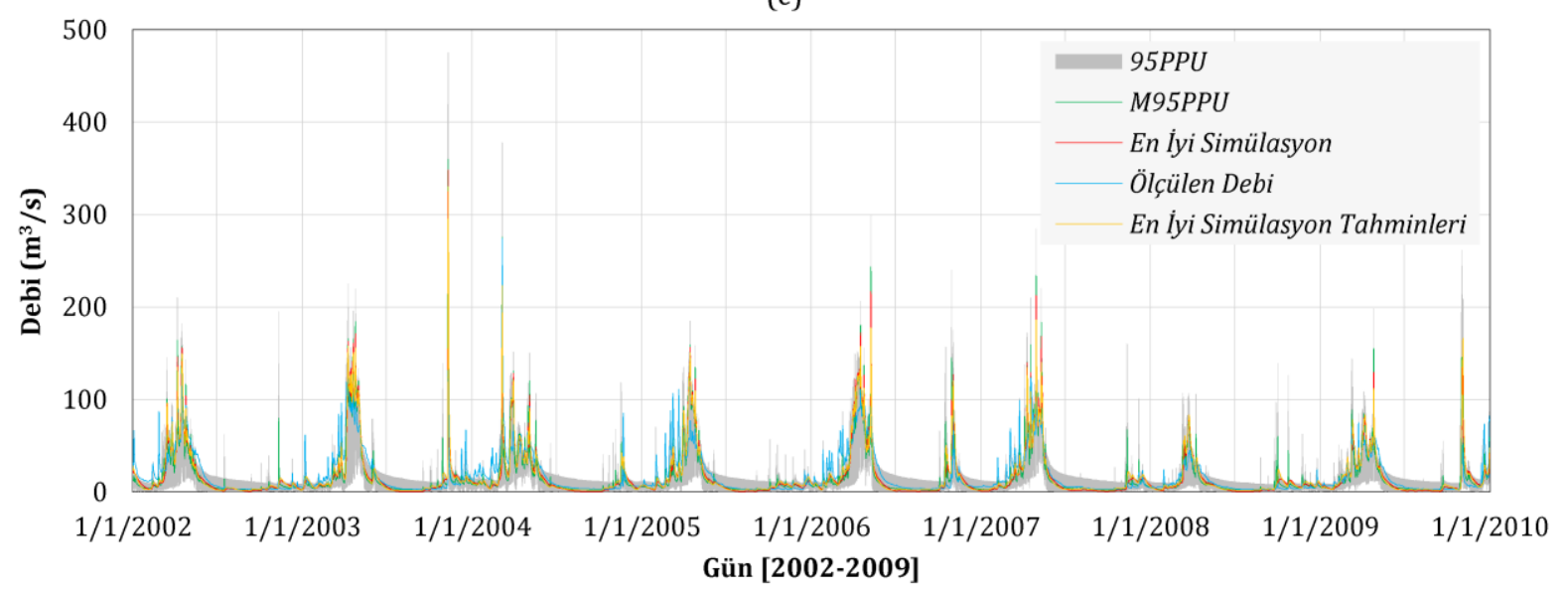

Şekil 3. Günlük model simülasyon sonuçları: (a) 1988-2001 periyodu için kalibrasyon öncesi SWAT model simülasyonu, (b) 1988-2001 periyodu için kalibre model simülasyonu ve (c) 2002-2009 periyodu için kalibre model simülasyonu.

21 Haziran'da kar için erime faktörü $\left(\mathrm{mm} \mathrm{H}_{2} \mathrm{O} /{ }^{\circ} \mathrm{C}-\right.$ gün) (SMFMX), kar yağış sıcaklığı ( $\left.{ }^{\circ} \mathrm{C}\right)$ (SFTMP) ve kar erimesi baz sıcaklığı $\left({ }^{\circ} \mathrm{C}\right)$ (SMTMP) parametrelerinin kar yağışı, kar birikimi ve kar erime süreçlerinin zaman ve miktarını karakterize ederek günlük akım simülasyonlarını doğrudan etkileyen en hassas parametreler olduğu tespit edilmiştir. Aylık model kalibrasyon sürecinde ise $b r^{2}$ değeri ilk adımda 0,85'e, ikinci adımda 0,92'ye yükselmiştir. Aylık model kalibrasyonunun ikinci adımında yine aynı altı kar parametresi hassas olarak nitelendirilmiştir. Global hassasiyet analizi istatistiklerine göre, bu parametreler arasında aylık akım simülasyonlarına etki eden en hassas 
(a)

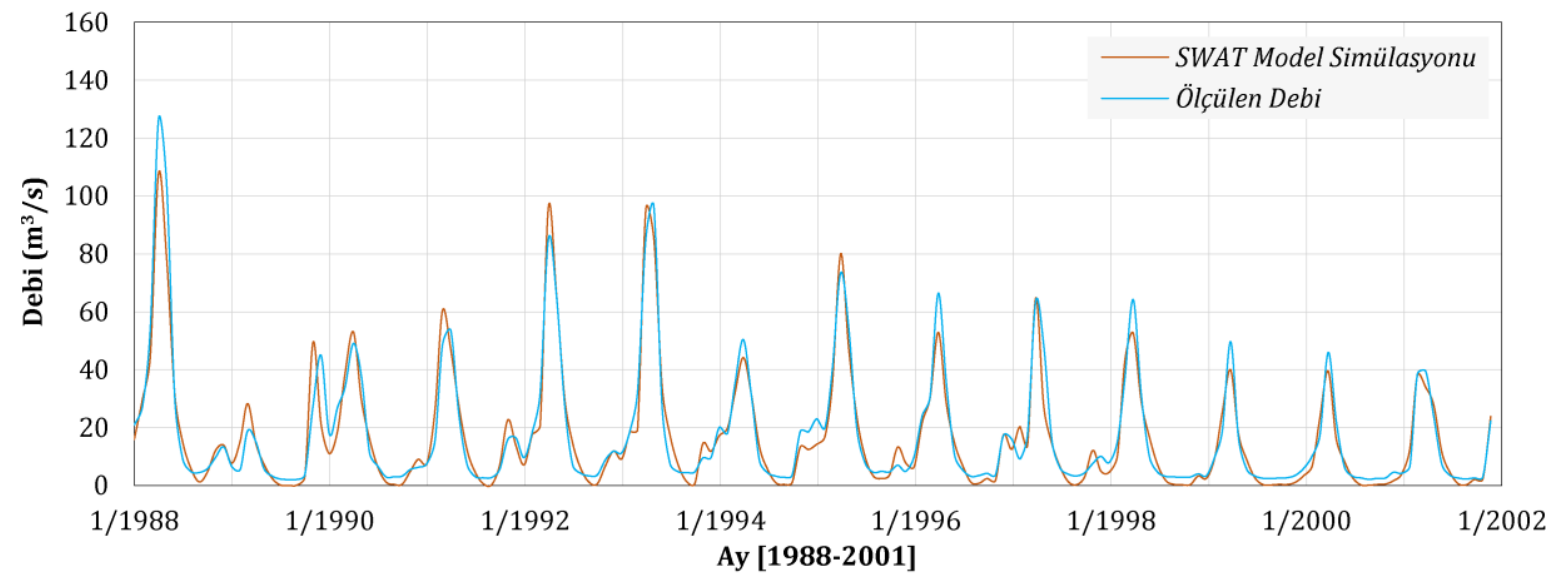

(b)

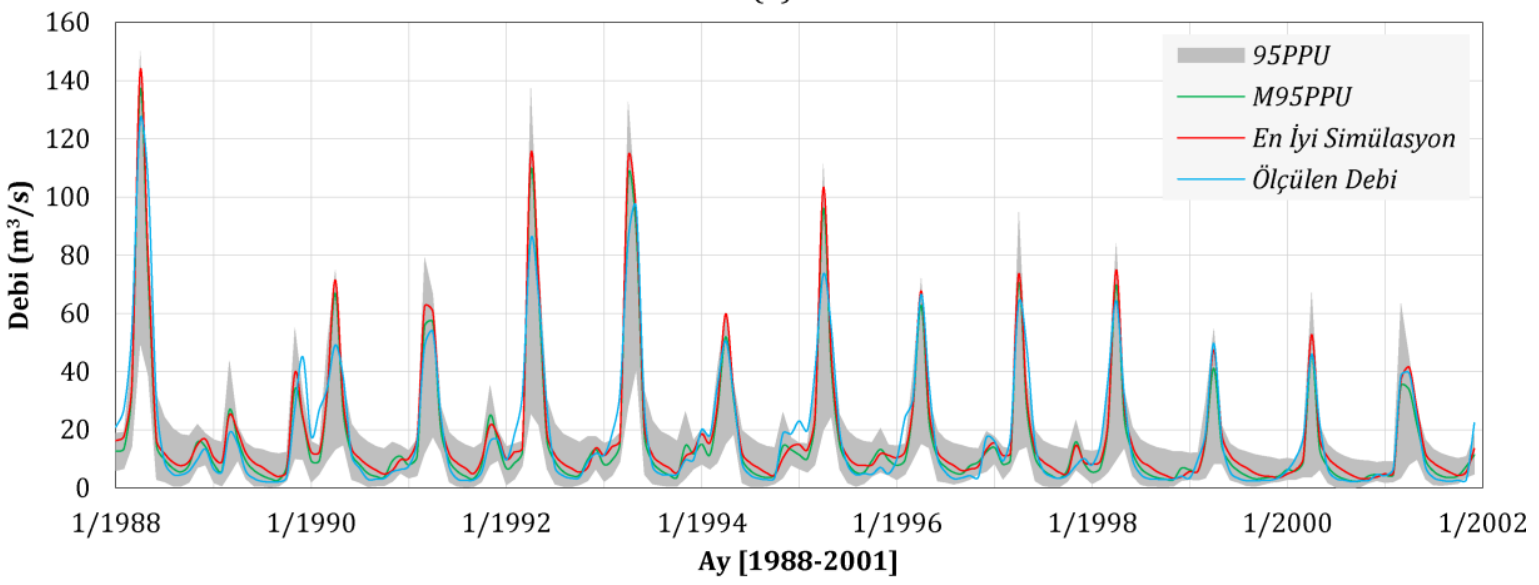

(c)

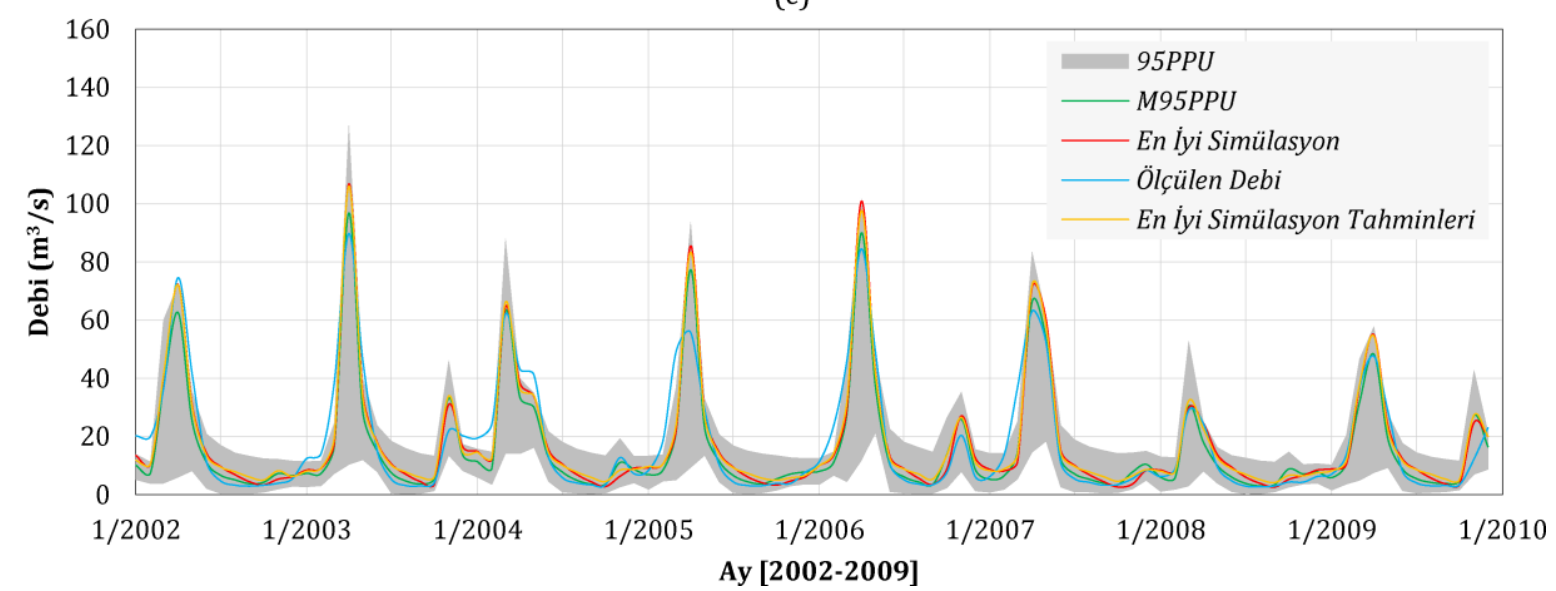

Şekil 4. Aylık model simülasyon sonuçları: (a) 1988-2001 periyodu için kalibrasyon öncesi SWAT model simülasyonu, (b) 1988-2001 periyodu için kalibre model simülasyonu ve (c) 2002-2009 periyodu için kalibre model simülasyonu.

parametreler sırasıyla SMTMP, SMFMX, SFTMP ve kar yığını sıcaklığı gecikme faktörü (TIMP) olmuştur.

Günlük ve aylık model kalibrasyon süreçlerinin son adımında, model proje veri tabanının yeraltı suyu, toprak, hidrolojik etki birimi, yönetim ve ana kanal girdi dosyalarında yer alan hassas model parametreleri gerçekleştirilen birleşik iterasyonlarla kalibre edilmiştir. Günlük model kalibrasyonu için gerçekleştirilen tekil hassasiyet analizleri sonucunda belirlenen 12 hassas model parametresi arasında global hassasiyet analizi sonuçlarına göre en hassas parametrelerin sırasıyla baz akım alfa faktörü (1/günler) (ALPHA_BF), yüzey akımı için 
Çizelge 1. Günlük ve aylık modeller için kalibre edilen parametreler.

\begin{tabular}{|c|c|c|c|c|c|}
\hline \multicolumn{3}{|c|}{ Günlük Model } & \multicolumn{3}{|c|}{ Aylık Model } \\
\hline Hassas Parametre & $\begin{array}{c}\text { Kalibre Parametre } \\
\text { Değer Aralığı }\end{array}$ & $\begin{array}{l}\text { En İyi Simülasyon } \\
\text { Parametre Değeri }\end{array}$ & Hassas Parametrea,b,c & $\begin{array}{c}\text { Kalibre Parametre } \\
\text { Değer Aralığı }\end{array}$ & $\begin{array}{l}\text { En İyi Simülasyon } \\
\text { Parametre Değeri }\end{array}$ \\
\hline
\end{tabular}

Aşama I

Sıcaklık ve yağış değişim oranlarıyla ilgili model parametrelerinin kalibrasyonu ve en iyi simülasyon değerlerine sabitlenmesi

$\begin{array}{lllllr}\text { v_TLAPS.sub } & - & -7,05 & \text { v_TLAPS.sub } & - & -7,05 \\ \text { v_PLAPS.sub } & - & 9,26 & \text { v_PLAPS.sub } & - & 9,26\end{array}$

Aşama II

Karla ilgili hassas model parametrelerinin kalibrasyonu ve en iyi simülasyon değerlerine sabitlenmesi

$\begin{array}{lllllc}\text { v_SMFMX.bsn } & - & 3,31 & \text { v_SMTMP.bsn } & 1,23 \\ \text { v_SFTMP.bsn } & - & 1,62 & \text { v_SMFMX.bsn } & - & 6,6 \\ \text { v_SMTMP.bsn } & - & -2,47 & \text { v_SFTMP.bsn } & - & 1,57 \\ \text { v_SNOCOVMX.bsn } & - & 38,86 & \text { v_TIMP.bsn } & - & 0,24 \\ \text { v_SMFMN.bsn } & - & 1,39 & \text { v_SMFMN.bsn } & - & 8,50 \\ \text { v_TIMP.bsn } & - & 0,75 & \text { v_SNOCOVMX.bsn } & - & 87,12\end{array}$

Aşama III

Diğer hassas model parametrelerinin kalibrasyonu

$\begin{array}{lcclcc}\text { v_ALPHA_BF.gw } & {[0-1]} & 0,77 & \text { v_ALPHA_BF.gw } & {[0-0,62]} & 0,13 \\ \text { r_OV_N.hru } & {[-0,9-199]} & 156,82 & \text { v_CH_K2.rte } & {[240,7-500]} & 252,88 \\ \text { v_RCHRG_DP.gw } & {[0-1]} & 0,59 & \text { r_SOL_AWC().sol } & {[-0,84-2,86]} & -0,56 \\ \text { v_CH_K2.rte } & {[-0,01-500]} & 462,5 & \text { r_SOL_K().sol } & {[80,71-244,2]} & 182,57 \\ \text { r_SOL_BD().sol } & {[-0,3-0,66]} & 0,06 & \text { v_GWQMN.gw } & {[1017-3673]} & 1349 \\ \text { r_SOL_K().sol } & {[-0,99-249,31]} & 15,28 & \text { v_GW_DELAY.gw } & {[53,7-351,3]} & 56,38 \\ \text { r_CN2.mgt } & {[-0,1-0,1]} & -0,07 & \text { v_GW_REVAP.gw } & {[0,11-0,2]} & 0,11 \\ \text { v_GWQMN.gw } & {[0-5000]} & 4455 & \text { r_SOL_Z().sol } & {[-0,7-1,04]} & 0,36 \\ \text { v_GW_REVAP.gw } & {[0,02-0,2]} & 0,16 & \text { r_CN2.mgt } & {[-0,1-0,01]} & -0,05 \\ \text { v_GW_DELAY.gw } & {[0-500]} & 400,5 & \text { v_RCHRG_DP.gw } & {[0,28-0,83]} & 0,67 \\ \text { r_SOL_AWC().sol } & {[-0,99-4,71]} & -0,51 & & & \\ \text { r_SOL_Z().sol } & {[-0,7-2,33]} & 0,95 & & & \end{array}$

a Parametreler, kalibrasyon sürecinin her aşaması için en hassas olandan başlanarak listelenmiştir.

b Parametre adlarının önündeki $\left(v_{-}\right)$niteleyicisi, geçerli parametre değerinin verilen aralıktaki bir değerle değiştirilmesini ifade ederken, (r_) niteleyicisi ise geçerli parametre değerinin verilen aralıktaki bir değerin 1 ile toplamıyla çarpılarak bağıl değişimini ifade eder.

c Kalibre parametre değer aralığı belirtilmemiş parametreler, ilgili kalibrasyon aşamasında kalibre edilerek en iyi simülasyon parametre değerlerine sabitlenmiş ve kalibrasyon sürecinin devamında bu değerler kullanılmıştır.

Çizelge 2. Günlük ve aylık modeller için kalibrasyon öncesi, kalibrasyon ve doğrulama süreçlerinde elde edilen simülasyon istatistikleri.

\begin{tabular}{|c|c|c|c|c|c|c|c|c|}
\hline $\begin{array}{l}\text { Simülasyon } \\
\text { Periyodu }\end{array}$ & Aşama & $\begin{array}{c}P \\
\text { Faktörü }\end{array}$ & $\begin{array}{c}R \\
\text { Faktörü }\end{array}$ & $b r^{2}$ & $b$ & NSE & $\begin{array}{c}\text { PBIAS } \\
(\%)\end{array}$ & RSR \\
\hline \multicolumn{9}{|c|}{ Günlük model } \\
\hline $1988-2001$ & SWAT model simülasyonu & - & - & 0,59 & 0,99 & 0,34 & 5,4 & 0,81 \\
\hline \multirow[t]{3}{*}{ 1988-2001 } & Model kalibrasyonu: Aşama I & - & - & 0,60 & 0,99 & 0,39 & 4,7 & 0,78 \\
\hline & Model kalibrasyonu: Aşama II & - & - & 0,65 & 1,00 & 0,47 & 3,4 & 0,73 \\
\hline & Model kalibrasyonu: Aşama III & 0,89 & 0,95 & 0,76 & 1,00 & 0,68 & 4,6 & 0,56 \\
\hline $2002-2009$ & Model doğrulaması & 0,87 & 1,10 & 0,74 & 1,01 & 0,64 & 10,2 & 0,60 \\
\hline \multicolumn{9}{|c|}{ Aylık model } \\
\hline $1988-2001$ & SWAT model simülasyonu & - & - & 0,84 & 0,91 & 0,92 & 5,0 & 0,28 \\
\hline \multirow[t]{3}{*}{$1988-2001$} & Model kalibrasyonu: Aşama I & - & - & 0,85 & 0,92 & 0,93 & 4,4 & 0,27 \\
\hline & Model kalibrasyonu: Aşama II & - & - & 0,92 & 1,00 & 0,91 & 3,2 & 0,30 \\
\hline & Model kalibrasyonu: Aşama III & 0,88 & 0,96 & 0,89 & 1,00 & 0,88 & $-4,6$ & 0,35 \\
\hline 2002-2009 & Model doğrulaması & 0,85 & 1,09 & 0,85 & 0,99 & 0,85 & $-0,8$ & 0,39 \\
\hline
\end{tabular}


Manning $n$ değeri (OV_N) ve derin akifer sızma fraksiyonu (RCHRG_DP) olduğu tespit edilmiştir. Aylık model kalibrasyonu için ise değerlendirilen 10 hassas parametreden aylık akım simülasyonlarına etki eden en hassas parametre ALPHA_BF olmuştur. Kalibrasyon süreçlerine dahil edilen tüm parametrelerin listesi, kalibre parametre değer aralıkları ve en iyi simülasyon parametre değerleri Çizelge 1'de sunulmuştur.

Kalibre modellerle elde edilen günlük ve aylık simülasyon sonuçları, istasyon ölçümleriyle birlikte sırasıyla Şekil 3b ve Şekil 4b'de gösterilmiştir. Günlük model kalibre parametre değer aralıkları $0,89^{\prime}$ luk bir $P$ faktörü ve $0,95^{\prime}$ lik bir $R$ faktörü değeri sağlamış olup, kalibre parametre değer aralıklarında gerçekleştirilen en iyi simülasyon için elde edilen $b r^{2}$, NSE, PBIAS ve RSR istatistikleri sırasıyla 0,76, 0,68, \%4,6 ve 0,56 olmuştur. Aylık model kalibre parametre değer aralıklarıyla ise $0,88^{\prime}$ lik bir $P$ faktörü ve $0,96^{\prime}$ lık bir $R$ faktörü değeri elde edilmiş olup, en iyi simülasyon için hesaplanan $b r^{2}$, NSE, PBIAS ve RSR istatistikleri sırasıyla 0,89, $0,88, \%-4,6$ ve 0,35 tir. Günlük ve aylık model kalibrasyon süreçleri boyunca elde edilen simülasyon istatistikleri Çizelge 2'de detaylı bir şekilde yer almaktadır.

Hem günlük hem de aylık model kalibre parametre değer aralıklarıyla, 1 civarı $R$ faktörü değeri ile tavsiye edilen \%70 değerinin oldukça üzerinde ve yaklaşık aynı oranda ölçüm değeri ( $P$ faktörü) yakalanabilmiştir (Abbaspour 2015). Kalibre modellerle hemen hemen aynı $P$ faktörü ve $R$ faktörü değerleri altında elde edilen en iyi simülasyon istatistikleri karşılaştırıldığında, aylık model performansının günlük modele göre daha iyi olduğu söylenebilir. Moriasi vd. (2007)'ye göre, elde edilen NSE, PBIAS ve RSR değerleri açısından kalibre model performansı günlük model için iyi, aylık model için ise çok iyi olarak tanımlanabilir. Her iki kalibrasyon süreci sonucunda da ölçülen ve simüle edilen akım değerleri arasındaki doğrusal regresyon çizgisi eğimi $(b)$ için hedeflenen 1 civarı bir değer yakalanabilmiştir. Ayrıca, günlük ve aylık modellerin en iyi simülasyonlarında 0,60'tan büyük değerlerin kabul edilebilir görüldüğü belirleme katsayısı $\left(r^{2}\right)$ için sırasıyla 0,76 ve 0,89 gibi yüksek değerlerin elde edilebilmiş olması, kalibre model performanslarının günlük ve aylık akım değerlerini simüle etmek için oldukça yeterli olduklarını göstermektedir (Santhi et al. 2001, Van Liew et al. 2007).

Baykan AGI'nin 1988-2001 periyodu ölçümlerine göre kalibre edilen modellerin 2002-2009 doğrulama periyodunda birer birleşik iterasyonla çalıştırılması sonucu elde edilen günlük ve aylık model çıktıları sırasıyla şekil $3 c$ ve şekil $4 c^{\prime}$ de gösterilmiş olup, doğrulama periyodu için elde edilen simülasyon istatistikleri Çizelge 2 'de detaylandırımıştır. Her iki doğrulama periyodu kalibre model simülasyonunda da ölçülen ve simüle edilen akım değerleri arasında kalibrasyon periyodundakilere göre daha düşük ilişkiler elde edilmiştir. Yine de gerek 1 civarı $R$ faktörü değerleri ile \%70 oranının oldukça üzerinde ölçüm değerleri yakalanabilmesi gerekse de günlük model için iyi, aylık model için ise çok iyi olarak nitelendirilebilecek en iyi simülasyon istatistikleri elde edilebilmesi açısından kalibre model performanslarının doğrulama periyodunda da oldukça yeterli olduğu görülmektedir (Abbaspour 2015, Moriasi et al. 2007, Santhi et al. 2001, Van Liew et al. 2007). Bu durum, her iki kalibrasyon sürecinde de kalibre parametre değer aralıklarının kalibrasyon periyodu akım değerleri için aşırı şartlandırımadığını ve dolayısıyla yapılan model kalibrasyonlarının başarısını göstermektedir.

\subsection{Günlük ve aylık SWAT modellerinin akım tahmin performansları}

Kalibre edilip doğrulanan günlük ve aylık SWAT modelleriyle akım ölçümleri olmadan sadece meteorolojik veriler kullanılarak yoğun kar yağışı ve birikimi gözlenen Baykan AGi havzasından gelen akımların ne derece doğru tahmin edilebileceği, en iyi simülasyon tahminleri ve M95PPU değerleri baz alınarak ayrı ayrı değerlendirilmiştir. Bu kapsamda, kalibrasyon periyodu en iyi simülasyon parametre değer setlerinin kullanılabilirliği, modellerin doğrulama periyodunda tek bir simülasyonla çalıştırılmasıyla elde edilen en iyi simülasyon 
Çizelge 3.Kalibrasyon ve doğrulama periyotları için elde edilen günlük model simülasyon istatistiklerinin karşılaştırılması.

\begin{tabular}{|c|c|c|c|c|c|c|c|}
\hline Model Tahmini & $b r^{2}$ & $\boldsymbol{b}$ & NSE & $\begin{array}{c}\text { PBIAS } \\
\text { (\%) }\end{array}$ & RSR & $\begin{array}{c}\bar{x} \_ \text {model } \\
\text { (x,_ölçülen) }\end{array}$ & 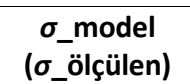 \\
\hline \multicolumn{8}{|c|}{ Kalibrasyon periyodu (1988-2001) } \\
\hline En iyi simülasyon & 0,76 & 1,00 & 0,68 & 4,6 & 0,56 & $17,18(18,02)$ & $29,18(25,54)$ \\
\hline M95PPU & 0,75 & 1,03 & 0,60 & 8,6 & 0,64 & $16,47(18,02)$ & $30,96(25,54)$ \\
\hline \multicolumn{8}{|c|}{ Doğrulama periyodu (2002-2009) } \\
\hline En iyi simülasyon & 0,74 & 1,01 & 0,64 & 10,2 & 0,60 & $16,08(17,90)$ & $26,58(22,70)$ \\
\hline M95PPU & 0,72 & 1,01 & 0,59 & 11,3 & 0,64 & $15,88(17,90)$ & $27,06(22,70)$ \\
\hline En iyi simülasyon tahminleri & 0,73 & 0,99 & 0,65 & 6,6 & 0,59 & $16,71(17,90)$ & $26,14(22,70)$ \\
\hline
\end{tabular}

Çizelge 4. Kalibrasyon ve doğrulama periyotları için elde edilen aylık model simülasyon istatistiklerinin karşılaştırılması.

\begin{tabular}{|c|c|c|c|c|c|c|c|}
\hline Model Tahmini & $b r^{2}$ & $\boldsymbol{b}$ & NSE & $\begin{array}{c}\text { PBIAS } \\
(\%)\end{array}$ & RSR & 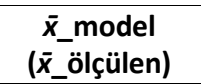 & $\begin{array}{c}\sigma \_ \text {model } \\
\text { (G_ölçülen) }\end{array}$ \\
\hline \multicolumn{8}{|c|}{ Kalibrasyon periyodu (1988-2001) } \\
\hline En iyi simülasyon & 0,89 & 1,00 & 0,88 & $-4,6$ & 0,35 & $18,87(18,04)$ & $22,88(21,56)$ \\
\hline M95PPU & 0,84 & 0,95 & 0,88 & 7,1 & 0,35 & $16,76(18,04)$ & $21,69(21,56)$ \\
\hline \multicolumn{8}{|c|}{ Doğrulama periyodu (2002-2009) } \\
\hline En iyi simülasyon & 0,85 & 0,99 & 0,85 & $-0,8$ & 0,39 & $18,07(17,93)$ & $20,71(19,56)$ \\
\hline M95PPU & 0,77 & 0,89 & 0,85 & 9,9 & 0,39 & $16,15(17,93)$ & $18,79(19,56)$ \\
\hline En iyi simülasyon tahminleri & 0,84 & 0,96 & 0,86 & $-3,1$ & 0,38 & $18,48(17,93)$ & $20,22(19,56)$ \\
\hline
\end{tabular}

tahminleriyle test edilmiştir. Modellerin M95PPU değerleri açısından tahmin performanslarını analiz etmek için ise modellerin hem kalibrasyon hem de doğrulama periyodunda kalibre parametre değer aralıkları için tek bir birleşik iterasyonla çalıştırılmasıyla elde edilen simülasyon sonuçlarının M95PPU değerlerine ait simülasyon istatistikleri kullanılmıştır.

Günlük model kullanılarak kalibrasyon periyodunda elde edilen M95PPU değerleri ile doğrulama periyodunda elde edilen en iyi simülasyon tahminleri ve M95PPU değerleri sırasıyla Şekil 3b ve Şekil $3 c^{\prime}$ de gösterilmiş olup, kalibrasyon ve doğrulama periyotları için hesaplanan simülasyon istatistikleri Çizelge 3'te listelenmiştir. M95PPU değerlerinin akım tahminlerinde kullanılabilirliğini kontrol etmek için kalibrasyon periyodu M95PPU değerlerinin simülasyon istatistikleri ile kalibrasyon periyodu en iyi simülasyon istatistikleri karşılaştırıldığında, M95PPU değerlerine göre model performansının hedef fonksiyon $b r^{2}$ değeri açısından değişiklik göstermediği ancak Moriasi vd. (2007) tarafından NSE, PBIAS ve RSR istatistikleri bazında yapılan sınıflandırmaya göre iyi seviyesinden yeterli seviyesine düştüğü görülmüştür. Doğrulama periyodu için hesaplanan M95PPU değerleri ile en iyi simülasyon tahminleri incelendiğinde ise M95PPU değerlerine göre model performansının kalibrasyon periyodu için yapılan değerlendirmeyle benzer nitelikte olduğu ancak en iyi simülasyon tahminlerine göre model performansının modelin doğrulama periyodu en iyi simülasyon performansına çok yakın olduğu ve Moriasi vd. (2007)'ye göre iyi olarak nitelendirilebileceği tespit edilmiştir.

Aylık model kullanılarak elde edilen kalibrasyon periyodu M95PPU değerleri Şekil 4b'de, doğrulama periyodu en iyi simülasyon tahminleri ile M95PPU değerleri ise Şekil $4 c^{\prime}$ de gösterilmiştir. Aylık model simülasyon istatistikleri Çizelge 4'te yer almaktadır. Kalibrasyon periyodu en iyi simülasyon istatistikleri ile kalibrasyon periyodu M95PPU değerleri için hesaplanan simülasyon istatistikleri karşılaştıııldığında, M95PPU değerlerine göre model performansının, $b r^{2}$ ve PBIAS istatistikleri bazında en iyi simülasyon performansından daha düşük olmasına rağmen halen çok iyi olarak tanımlanabileceği görülmüştür (Moriasi et al. 2007). Aynı durum, doğrulama periyodu M95PPU değerleri açısından da geçerli olup, M95PPU 


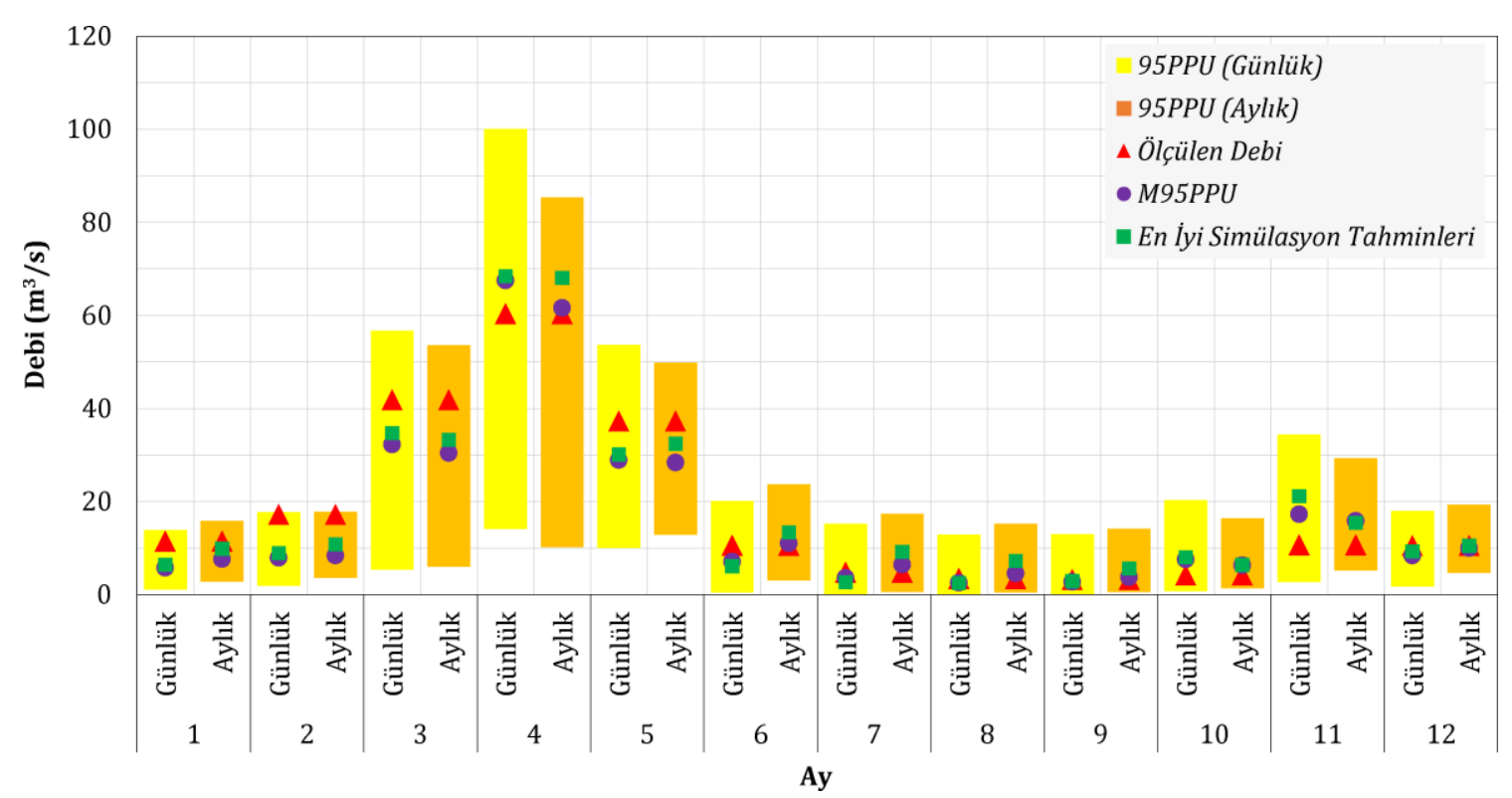

Şekil 5. Günlük ve aylık model simülasyonlarının doğrulama periyodu ortalama aylık akım tahminlerinin karşılaştırması.

Çizelge 5. Doğrulama periyodu için elde edilen günlük ve aylık model simülasyon istatistiklerinin aylık bazda karşılaştırılması.

\begin{tabular}{|c|c|c|c|c|c|c|c|}
\hline Model Tahmini & $b r^{2}$ & $\boldsymbol{b}$ & NSE & $\begin{array}{l}\text { PBIAS } \\
(\%)\end{array}$ & RSR & $\begin{array}{c}\bar{x} \_ \text {model } \\
\text { (x,_ölçülen) }\end{array}$ & 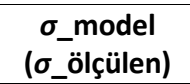 \\
\hline \multicolumn{8}{|c|}{ Günlük model (aylık ortalama) } \\
\hline M95PPU & 0,85 & 0,99 & 0,83 & 11,3 & 0,41 & $15,90(17,93)$ & $20,77(19,56)$ \\
\hline En iyi simülasyon tahminleri & 0,86 & 1,01 & 0,82 & 6,6 & 0,43 & $16,74(17,93)$ & $21,33(19,56)$ \\
\hline \multicolumn{8}{|c|}{ Aylık model } \\
\hline M95PPU & 0,77 & 0,89 & 0,85 & 9,9 & 0,39 & $16,15(17,93)$ & $18,79(19,56)$ \\
\hline En iyi simülasyon tahminleri & 0,84 & 0,96 & 0,86 & $-3,1$ & 0,38 & $18,48(17,93)$ & $20,22(19,56)$ \\
\hline
\end{tabular}

değerlerine göre model performansındaki düşüş kalibrasyon periyodundakinden çok daha belirgindir. Günlük model en iyi simülasyon tahminleri için yapılan değerlendirmeye benzer olarak, aylık modelin doğrulama periyodu en iyi simülasyon tahminleri ile doğrulama periyodu en iyi simülasyon değerleri arasında da istatistiksel olarak belirgin bir fark olmadığı tespit edilmiştir.

Aylık akım tahminleri için günlük model kullanımının tahmin performansında bir katkısının olup olmadığını incelemek amacıyla, günlük model kullanılarak doğrulama periyodu için elde edilen günlük ortalama M95PPU değerleri ve en iyi simülasyon tahminlerinin aylık ortalamaları hesaplanarak doğrulama periyodu aylık model tahminleri ile karşılaştırılmıştır. Buna göre, günlük ve aylık model simülasyonlarının doğrulama periyodu ortalama aylık akım tahminleri Şekil 5'te gösterilmiş olup, elde edilen simülasyon istatistikleri Çizelge 5'te listelenmiştir. Günlük model kullanılarak elde edilen M95PPU değerleri ile en iyi simülasyon tahminlerinin aylık ortalamalarının, $b r^{2}$ değerleri açısından aylık model sonuçlarına göre daha iyi olduğu görülmüş ise de değerlendirmeye alınan NSE, PBIAS ve RSR istatistikleri açısından aylık model tahminlerinin kısmen daha başarılı olduğu saptanmıştır. Dolayısıyla, aylık akım tahminleri için günlük model kullanımının hem M95PPU değerleri hem de en iyi simülasyon tahminleri bazında belirgin bir fark yaratmadığı söylenebilir.

\subsection{Günlük ve aylık SWAT modellerinin kullanılabilirliklerinin değerlendirilmesi}

Günlük ve aylık modellerin Bitlis Çayı havzasında planlanan HES'lerin kurulu güç optimizasyonları ve güvenilir enerji hesaplamalarında kullanılabilirliklerini değerlendirebilmek amacıyla, tüm analiz periyodu (1988-2009) için elde edilen M95PPU değerleri ile en iyi simülasyon 
(a)

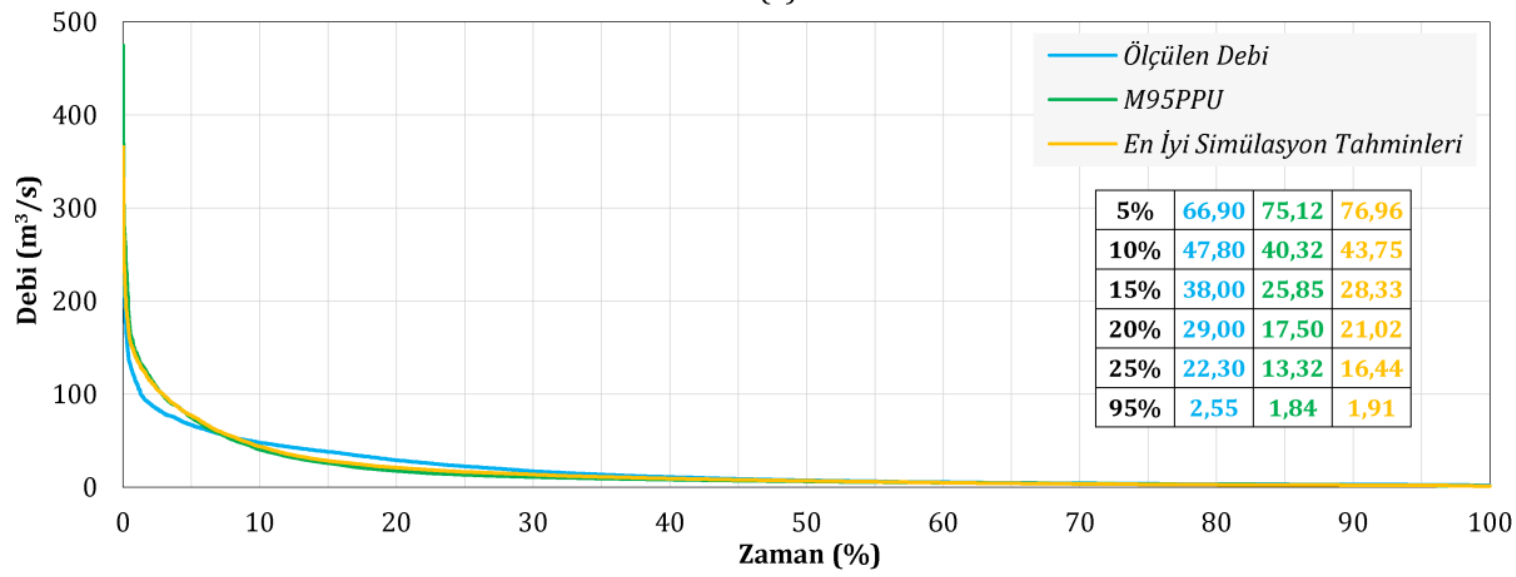

(b)

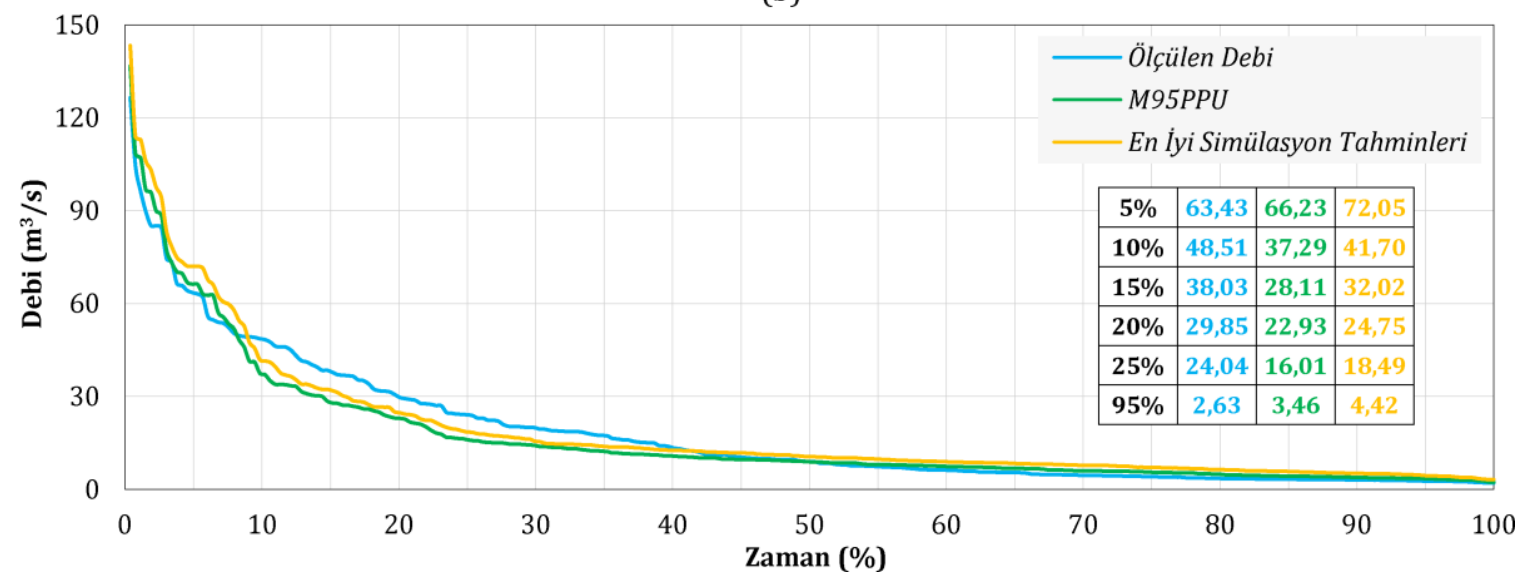

Şekil 6. 1988-2009 periyodu için günlük ve aylık model simülasyonları ile elde edilen akım tahminlerinin (a) günlük ve (b) aylık debi-süreklilik eğrilerinin karşılaştırıması.

tahminlerinin debi-süreklilik ilişkileri incelenmiştir. Günlük ve aylık model tahminleri için çizilen günlük ve aylık debi-süreklilik eğrileri sırasıyla Şekil 6a ve Şekil 6b'de gösterilmiştir. Buna göre, hem günlük hem de aylık model simülasyonları ile elde edilen akım tahminlerinin, özellikle aşılma olasılığı \%30'un altında olan debilerde kısmi farklar görülse de Bitlis Çayı́nın Baykan AGi yerindeki akım karakteristiklerini önemli bir değişime sebep olmadan yansıtabildikleri görülmektedir. Nehir tipi HES'lerin güvenilir enerji hesapları için değerlendirilen zamanın \%95'inde geçen günlük ortalama akım değeri, Baykan AGi ölçümlerine göre $2,55 \mathrm{~m}^{3} / \mathrm{s}$ iken M95PPU değerlerine göre $1,84 \mathrm{~m}^{3} / \mathrm{s}$, en iyi simülasyon tahminlerine göre ise $1,91 \mathrm{~m}^{3} / \mathrm{s}$ olarak bulunmuştur. Nehir tipi HES'lerin kurulu güç optimizasyonları için değerlendirilen zamanın \% $5^{\prime} \mathrm{i}$ ila \%25'inde geçen günlük ortalama akım değer aralığı (AE Su 2009); Baykan AGi ölçümlerine göre 22,30-66,90 m³ $/ \mathrm{s}$, M95PPU değerlerine göre 13,32$75,12 \mathrm{~m}^{3} / \mathrm{s}$ ve en iyi simülasyon tahminlerine göre
16,44-76,96 $\mathrm{m}^{3} / \mathrm{s}$ olarak hesaplanmıştır. Depolamalı HES'lerin kurulu güç optimizasyonları için değerlendirilen zamanın \%5'i ila \%25'inde geçen aylık ortalama akım değer aralığı (Yalcin and Tigrek 2016) ise Baykan AGi ölçümlerine göre 24,04-63,43 m³ $/ \mathrm{s}$, M95PPU değerlerine göre 16,01$66,23 \mathrm{~m}^{3} / \mathrm{s}$ ve en iyi simülasyon tahminlerine göre $18,49-72,05 \mathrm{~m}^{3} / \mathrm{s}$ olarak hesaplanmıştır.

Ayrıca, günlük model kullanılarak elde edilen günlük ortalama M95PPU değerleri ile en iyi simülasyon tahminlerinin, Bitlis Çayı havzasında planlanan HES'lerin dolusavak ve derivasyon yapılarının boyutlandırılabilmesi için uygulanabilecek noktasal ve/veya bölgesel taşkın analizlerinde kullanılabilirlikleri incelenmiştir (DSi 2012). Bu kapsamda, doğrulama periyodunun istatistiksel olarak bir değerlendirme yapabilmek için oldukça kısa olması sebebiyle tüm analiz periyodu için elde edilen yıllık maksimum günlük akım tahminleri baz alınmış olup, bu tahminler için 


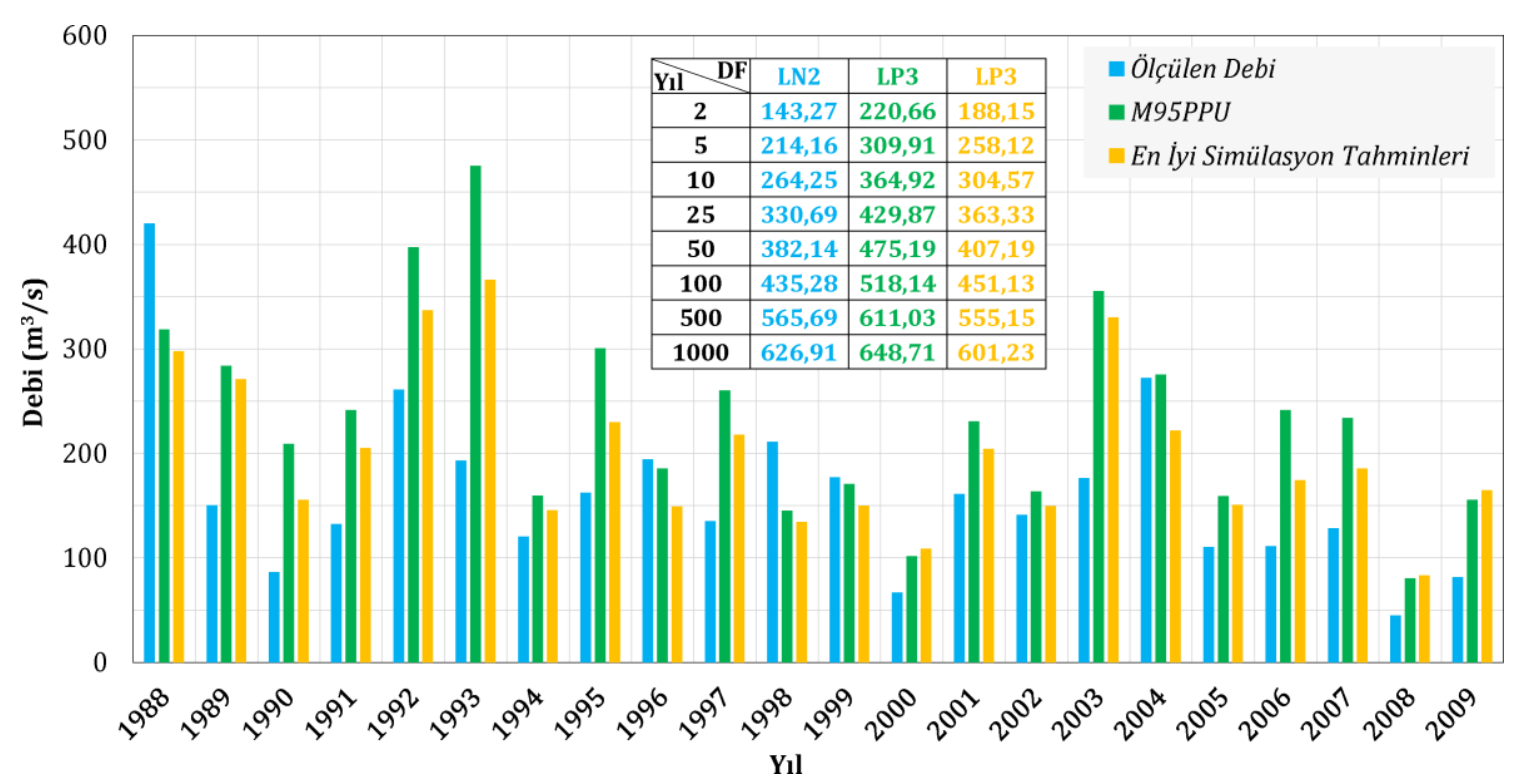

Şekil 7. 1988-2009 periyodu için günlük model simülasyonu ile elde edilen yıllık maksimum günlük akım tahminleri ve bu tahminler için en uygun frekans dağılım fonksiyonlarına göre hesaplanan tekerrürlü taşkın debilerinin karşılaştırılması.

en uygun frekans dağııım fonksiyonları kullanılarak tekerrürlü taşkın debileri hesaplanmıştır (Özdemir 1978). Kolmogorov-Smirnov test sonuçlarına göre, Baykan AGi'de ölçülen yıllık maksimum günlük ortalama akım değerlerine en uygun dağılım fonksiyonu iki parametreli Log-Normal (LN2) iken M95PPU değerleri ve en iyi simülasyon tahminleri için en uygun dağılım fonksiyonu Log-Pearson Tip 3 (LP3) olmuştur. Bu dağılım fonksiyonları kullanılarak elde edilen 25, 50, 100 ve 1000 yıl tekerrürlü taşkın debileri ise Baykan AGi ölçümleri için $330,69 \mathrm{~m}^{3} / \mathrm{s}, 382,14 \mathrm{~m}^{3} / \mathrm{s}, 435,28 \mathrm{~m}^{3} / \mathrm{s}$ ve $626,91 \mathrm{~m}^{3} / \mathrm{s}$; M95PPU değerleri için $429,87 \mathrm{~m}^{3} / \mathrm{s}$, $475,19 \mathrm{~m}^{3} / \mathrm{s}, 518,14 \mathrm{~m}^{3} / \mathrm{s}$ ve $648,71 \mathrm{~m}^{3} / \mathrm{s}$; en iyi simülasyon tahminleri için $363,33 \mathrm{~m}^{3} / \mathrm{s}, 407,19$ $\mathrm{m}^{3} / \mathrm{s}, 451,13 \mathrm{~m}^{3} / \mathrm{s}$ ve $601,23 \mathrm{~m}^{3} / \mathrm{s}^{\prime}$ dir (Şekil 7). Baykan AGi ölçümlerine göre hesaplanan 25 yıl ve üzeri tekerrürlü taşkın debileri ile model tahminlerine göre hesaplanan tekerrürlü taşkın debileri arasındaki yüzde hata istatistikleri M95PPU değerleri için en fazla \%29,99, en iyi simülasyon tahminleri için ise en fazla \%9,87'dir. Her ne kadar yıllık maksimum günlük akım değerleri açısından ölçüm değerleri ile model tahminleri arasında düşük korelasyon ilişkileri (M95PPU değerleri için $r=0,55$ - en iyi simülasyon tahminleri için $r=0,59$ ) elde edilmiş olsa da özellikle en iyi simülasyon tahminleriyle hesaplanan tekerrürlü taşkın debileri ile ölçüm değerlerine göre hesaplanan tekerrürlü taşkın debilerinin birbirleriyle uyumlu olduğu görülmektedir.

\section{Sonuç}

Bu çalışmada, küresel kapsamlı açık erişim veri tabanlarından elde edilen sayısal yükseklik modeli, arazi kullanım/arazi örtüsü ve toprak verileri ile yerel meteoroloji istasyonlarının günlük meteorolojik ölçümleri kullanılarak oluşturulan bir SWAT modelinin, yoğun kar yağışı ve birikimi gözlenen bir havzaya sahip Bitlis Çayı'nın Baykan AGi yerindeki günlük ve aylık ortalama akım değerleri bazında simülasyon ve tahmin performansı değerlendirilmiştir. Kurulan SWAT modeli, günlük ve aylık akım simülasyonları için Baykan AGi kayıtlarına göre ayrı ayrı kalibre edilip doğrulanmıştır. Günlük ve aylık model kalibre parametre değer aralıklarında gerçekleştirilen birleşik iterasyonlarla hem kalibrasyon hem de doğrulama periyodu için 1 civarı $R$ faktörü ve tavsiye edilen $\% 70$ oranının oldukça üzerinde $P$ faktörü değerlerine sahip PPU bantları oluşturulabilmiş ve günlük model için iyi, aylık model için ise çok iyi olarak nitelendirilebilecek en iyi simülasyon istatistikleri elde edilebilmiştir. 
Elde edilen en iyi simülasyon istatistikleri gerçekleştirilen birleşik iterasyonlarda AGi ölçüm verilerine göre en yüksek hedef fonksiyon değerlerini veren simülasyonlara ait olduğundan, sadece meteoroloji istasyonlarının verileri kullanılarak Baykan AGI havzasından gelen akımların ne derece doğru tahmin edilebileceği, M95PPU değerleri ve en iyi simülasyon tahminleri baz alınarak ayrı ayrı değerlendirilmiştir. Buna göre, M95PPU değerlerine göre günlük ve aylık modellerin akım tahmin performanslarında kısmı bir düşüş görülmekle birlikte en iyi simülasyon tahminlerine göre model performanslarında istatistiksel olarak belirgin bir fark görülmemiştir. Ayrıca, günlük model tahminlerinin aylık ortalamaları alınarak aylık model tahminleri ile karşılaştırıldığında, aylık akım tahminleri için günlük model kullanımının hem M95PPU değerleri hem de en iyi simülasyon tahminleri bazında belirgin bir fark yaratmadığı tespit edilmiştir.

Sonuç olarak, kurulan SWAT modelinin günlük ve aylık akım simülasyonları için ayrı ayrı kalibre edilmesi ile elde edilen günlük ve aylık modeller, hem M95PPU değerleri hem de en iyi simülasyon tahminleri bazında gerek istatistiksel değerlendirme indeksleri gerekse de akım-süreklilik ilişkileri bağlamında tatmin edici tahmin performansları sunabilmişlerdir. Ancak, günlük modelin yıllık maksimum günlük akım tahminleri kullanılarak elde edilen tekerrürlü taşkın debileri her ne kadar Baykan AGi ölçümlerine göre hesaplanan tekerrürlü taşkın debilerine yakın olsalar da günlük model yıllık maksimum akım tahminleri ile istasyon ölçümleri arasında güçlü bir korelasyon elde edilememiştir. Bu durum; hidrometeorolojik ölçüm kalitesi, teorik model, model parametreleri gibi yönetimi zor belirsizlik kaynakları sebepli olabileceği gibi, günlük akım simülasyonları için model kurulumunda daha fazla detay içeren büyük ölçekli mekansal veri setlerinin kullanımı denenebilir.

Geliştirilen modellerle hem akım-süreklilik ilişkileri hem de tekerrürlü taşkın debileri bağlamında ölçüm değerleriyle uyumlu tahmin performansları elde edilebilmiş olması, bu modellerin, gelecek on yıllarda Bitlis Çayı'nın akım rejiminde meydana gelebilecek olası değişimlerin günlük ve aylık bazda incelenebilmesine olanak sağlayabileceğini göstermektedir. Geliştirilen modeller, iklim değişikliği senaryoları için üretilen küresel ölçekli iklim projeksiyonlarının bölgesel ölçeğe indirgenmesiyle elde edilebilecek yağış ve sıcaklık verileriyle çalıştırılabilir. Bu kapsamda elde edilebilecek akım tahminlerinin, havza HES projelerinin planlama ve işletme politikalarının yeniden değerlendirilerek havza su potansiyelinin daha verimli kullanılmasına destek olabileceği düşünülmektedir.

\section{Kaynaklar}

Abbas, T., Hussain, F., Nabi, G., Boota, M.W. and Wu, R.S., 2019. Uncertainty evaluation of SWAT model for snowmelt runoff in a Himalayan watershed. Terrestrial, Atmospheric and Oceanic Sciences, 30(2), 265-279.

Abbaspour, K.C., 2015. SWAT-CUP: SWAT Calibration and Uncertainty Programs - A User Manual. Eawag Swiss Federal Institute of Aquatic Science and Technology, Dübendorf, 100.

Abbaspour, K.C., Johnson, C.A. and van Genuchten, M.Th., 2004. Estimating uncertain flow and transport parameters using a sequential uncertainty fitting procedure. Vadouse Zone Journal, 3(4), 1340-1352.

Abbaspour, K.C., Rouholahnejad, E., Vaghefi, S., Srinivasan, R., Yang, H. and Kløve, B., 2015. A continental-scale hydrology and water quality model for Europe: Calibration and uncertainty of a highresolution large-scale SWAT model. Journal of Hydrology, 524, 733-752.

Abbaspour, K.C., Yang, J., Maximov, I., Siber, R., Bogner, K., Mieleitner, J., Zobrist, J. and Srinivasan, R., 2007. Modelling hydrology and water quality in the prealpine/alpine Thur watershed using SWAT. Journal of Hydrology, 333(2-4), 413-430.

Adam, J.C., Hamlet, A.F. and Lettenmaier, D.P., 2009. Implications of global climate change for snowmelt hydrology in the twenty-first century. Hydrological Processes, 23(7), 962-972.

AE Su (AE Su Mühendislik Limited Şirketi), 2009. Başören Regülatörü ve HES Fizibilite Raporu. $A E$ Su Mühendislik Limited Şirketi, Ankara, 161. 
Ahl, R.S., Woods, S.W. and Zuuring, H.R., 2008. Hydrologic calibration and validation of SWAT in a snow-dominated Rocky Mountain watershed, Montana, USA. Journal of the American Water Resources Association, 44(6), 1411-1430.

Al-Khafaji, M.S. and Saeed, F.H., 2018. Effect of DEM and land cover resolutions on simulated runoff of Adhaim Watershed by SWAT model. Engineering and Technology Journal (Part A: Engineering), 36(4), 439448.

Arnold, J.G., Kiniry, J.R., Srinivasan, R., Williams, J.R., Haney, E.B. and Neitsch, S.L., 2013. Soil \& Water Assessment Tool Input/output Documentation (Version 2012). Texas Water Resources Institute, Texas, 650.

Arnold, J.G., Moriasi, D.N., Gassman, P.W., Abbaspour, K.C., White, M.J., Srinivasan, R., Santhi, C., Harmel, R.D., van Griensven, A., Liew, M.W.V., Kannan, N. and Jha, M.K., 2012. SWAT: Model use, calibration, and validation. Transactions of the ASABE, 55(4), 1491-1508.

Arnold, J.G., Srinivasan, R., Muttiah, R.S. and Williams, J.R., 1998. Large area hydrologic modeling and assessment - Part I: Model development. Journal of the American Water Resources Association, 34(1), 73-89.

Aydin, M.C. and Işhik, E., 2015. Evaluation of ground snow loads in the micro-climate regions. Russian Meteorology and Hydrology, 40(11), 741-748.

Aydın, M.C. ve Yaylak M.M., 2016. Bitlis Çayı taşkın hidrolojisi. Bitlis Eren Üniversitesi Fen Bilimleri Dergisi, 5(1), 49-58.

Bozkurt, D. and Sen, O.L., 2013. Climate change impacts in the Euphrates-Tigris Basin based on different model and scenario simulations. Journal of Hydrology, 480, 149-161.

Daggupati, P., Srinivasan, R., Ahmadi, M. and Verma, D., 2017. Spatial and temporal patterns of precipitation and stream flow variations in Tigris-Euphrates river basin. Environmental Monitoring and Assessment, 189(2), 50.

Douglas-Mankin, K.R., Srinivasan, R. and Arnold, J.G., 2010. Soil and Water Assessment Tool (SWAT) model: Current developments and applications. Transactions of the ASABE, 53(5), 14231431.

DSi (Devlet Su İşleri Genel Müdürlüğü), 2012. Taşkınlar Hidrolojisi Tasarım Rehberi. Devlet Su İşleri Genel Müdürlüğü, Ankara, 56.
EIE (Elektrik İşleri Etüt İdaresi Genel Müdürlüğü), 1990. Bitlis Çayı İstikşaf Raporu. Elektrik İşleri Etüt İdaresi Genel Müdürlüğü, Ankara, 110.

Fontaine, T.A., Cruickshank, T.S., Arnold, J.G. and Hotchkiss, R.H., 2002. Development of a snowfallsnowmelt routine for mountainous terrain for the Soil Water Assessment Tool (SWAT). Journal of Hydrology, 262(1-4), 209-223.

Gassman, P.W., Reyes, M.R., Green, C.H. and Arnold, J.G., 2007. The Soil and Water Assessment Tool: Historical development, applications, and future research directions. Transactions of the ASABE, 50(4), 1211-1250.

Gassman, P.W., Sadeghi, A.M. and Srinivasan, R., 2014. Applications of the SWAT model special section: Overview and insights. Journal of Environmental Quality, 43(1), 1-8.

Geza, M. and McCray, J.E., 2008. Effects of soil data resolution on SWAT model stream flow and water quality predictions. Journal of Environmental Management, 88(3), 393-406.

Glavan, M. and Pintar, M., 2012. Strengths, Weaknesses, Opportunities and Threats of Catchment Modelling with Soil and Water Assessment Tool (SWAT) Model. ss 39-64. Nayak, P., ed. Water Resources Management and Modeling. InTech, Rijeka, 310.

Grusson, Y., Sun, X., Gascoin, S., Sauvage, S., Raghavan, S., Anctil, F. and Sáchez-Pérez, J.-M., 2015. Assessing the capability of the SWAT model to simulate snow, snow melt and streamflow dynamics over an alpine watershed. Journal of Hydrology, 531(3), 574-588.

Himanshu, S.K., Garg, N., Rautela, S., Anuja, K.M. and Tiwari, M., 2013. Remote sensing and GIS applications in determination of geomorphological parameters and design flood for a Himalayan river basin, India. International Research Journal of Earth Sciences, 1(3), 11-15.

IPCC (Intergovernmental Panel on Climate Change), 2013. Climate Change 2013: The Physical Science Basis - Working Group I Contribution to the Fifth Assessment Report of the Intergovernmental Panel on Climate Change. Stocker, T.F., Qin, D., Plattner, G.K., Tignor, M.M.B., Allen, S.K., Boschung, J., Nauels, A., Xia, Y., Bex, V., Midgley, P.M., ed. Cambridge University Press, New York, 1535.

IPCC (Intergovernmental Panel on Climate Change), 2014. Climate Change 2014: Impacts, Adaptation, and Vulnerability Part A: Global and Sectoral Aspects - Working Group II Contribution to the Fifth Assessment Report of the Intergovernmental Panel 
on Climate Change. Field, C.B., Barros, V.R., Dokken, D.J., Mach, K.J., Mastrandrea, M.D., Bilir, T.E., Chatterjee, M., Ebi, K.L., Estrada, Y.O., Genova, R.C., Girma, B., Kissel, E.S., Levy, A.N., MacCracken, S., Mastrandrea, P.R., White, L.L., ed. Cambridge University Press, New York, 1132.

Katz, R.W. and Brown, B.G., 1992. Extreme events in a changing climate: Variability is more important than averages. Climatic Change, 21(3), 289-302.

Lemann, T., Roth, V. and Zeleke, G., 2017. Impact of precipitation and temperature changes on hydrological responses of small-scale catchments in the Ethiopian Highlands. Hydrological Sciences Journal, 62(2), 270-282.

Liu, Y., Cui, G. and Li, H., 2020. Optimization and application of snow melting modules in SWAT model for the alpine regions of northern China. Water, 12(3), 636.

Luo, Y., Arnold, J., Allen, P. and Chen, X., 2012. Baseflow simulation using SWAT model in an inland river basin in Tianshan Mountains, Northwest China. Hydrology and Earth System Sciences, 16(4), 1259-1267.

MGM (Meteoroloji Genel Müdürlüğü), 2018a. 17207Bitlis Meteoroloji İstasyonu Uzun Yıllar Tüm Parametreler Bülteni (1959-2009). Meteoroloji Genel Müdürlüğü, Ankara.

MGM (Meteoroloji Genel Müdürlüğü), 2018b. 17210Siirt Meteoroloji İstasyonu Uzun Yıllar Tüm Parametreler Bülteni (1939-2017). Meteoroloji Genel Müdürlüğü, Ankara.

MGM (Meteoroloji Genel Müdürlüğü), 2018c. 17207Bitlis Meteoroloji İstasyonu Günlük Toplam Yağış, Maksimum ve Minimum Sıcaklık, Ortalama Nispi Nem, Ortalama Rüzgar Hızı ve Toplam Güneşlenme Şiddeti Ölçümleri (1959-2009). Meteoroloji Genel Müdürlüğü, Ankara.

MGM (Meteoroloji Genel Müdürlüğü), 2018d. 17210Siirt Meteoroloji İstasyonu Günlük Toplam Yağış, Maksimum ve Minimum Sıcaklık, Ortalama Nispi Nem, Ortalama Rüzgar Hızı ve Toplam Güneşlenme Şiddeti Ölçümleri (1939-2017). Meteoroloji Genel Müdürlüğü, Ankara.

MGM (Meteoroloji Genel Müdürlüğü), 2018e. 17207Bitlis Meteoroloji İstasyonu Yıllık Standart Zamanlarda Gözlenen En Büyük Yağış Değerleri (1966-2009). Meteoroloji Genel Müdürlüğü, Ankara.

MGM (Meteoroloji Genel Müdürlüğü), 2018f. 17210-Siirt Meteoroloji İstasyonu Yıllık Standart Zamanlarda
Gözlenen En Büyük Yağış Değerleri. Meteoroloji Genel Müdürlüğü (1959-2015), Ankara.

Moriasi, D.N., Arnold, J.G., Van Liew, M.W., Bingner, R.L., Harmel, R.D. and Veith, T.L., 2007. Model evaluation guidelines for systematic quantification of accuracy in watershed simulations. Transactions of the ASABE, 50(3), 885-900.

Omani, N., Srinivasan, R., Karthikeyan, R. and Smith, P.K., 2017. Hydrological modeling of highly glacierized basins (Andes, Alps, and Central Asia). Water, 9(2), 111.

Özdemir, H., 1978. Uygulamalı Taşkın Hidrolojisi. Devlet Su İşleri Genel Müdürlüğü, Ankara, 221.

Pandey, A., Himanshu, S.K., Mishra, S.K. and Singh, V.P., 2016. Physically based soil erosion and sediment yield models revisited. CATENA, 147, 595-620.

Pradhanang, S.M., Anandhi, A., Mukundan, R., Zion, M.S., Pierson, D.C., Schneiderman, E.M., Matonse, A. and Frei, A., 2011. Application of SWAT model to assess snowpack development and streamflow in the Cannonsville watershed, New York, USA. Hydrological Processes, 25(21), 3268-3277.

Rahaman, M.M., Lamichhane, G.R., Shrestha, A., Thakur, B., Kalra, A. and Ahmad, S., 2019. Using SWAT to simulate streamflow in Trinity River Basin, Texas, USA. World Environmental and Water Resources Congress 2019: Watershed Management, Irrigation and Drainage, and Water Resources Planning and Management, 19-23 Mayıs, Pittsburgh, 421-435.

Rahman, K., Maringanti, C., Beniston, M., Widmer, F., Abbaspour, K. and Lehmann, A., 2013. Streamflow modeling in a highly managed mountainous glacier watershed using SWAT: The Upper Rhone River watershed case in Switzerland. Water Resources Management, 27(2), 323-339.

Santhi, C., Arnold, J.G., Williams, J.R., Dugas, W.A., Srinivasan, R. and Hauck, L.M., 2001. Validation of the SWAT model on a large river basin with point and nonpoint sources. Journal of the American Water Resources Association, 37(5), 1169-1188.

Sharifi, A. and Kalin, L., 2010. Effect of land use uncertainty on watershed modeling. World Environmental and Water Resources Congress 2010: Challenges of Change, 16-20 Mayıs, Providence, 4730-4739.

Shrestha, S., Shrestha, M. and Shrestha, P.K., 2018. Evaluation of the SWAT model performance for simulating river discharge in the Himalayan and 
tropical basins of Asia. Hydrology Research, 49(3), 846-860.

Singh, V.P., 1995. Computer Models of Watershed Hydrology. Water Resources Publications, Highlands Ranch, 1144.

Stratton, B.T., Sridhar, V., Gribb, M.M., McNamara, J.P. and Narasimhan, B., 2009. Modeling the spatially varying water balance processes in a semiarid mountainous watershed of Idaho. Journal of the American Water Resources Association, 45(6), 13901408.

Tan, M.L., Ramli, H.P. and Tam, T.H., 2018. Effect of DEM resolution, source, resampling technique and area threshold on SWAT outputs. Water Resources Management, 32(14), 4591-4606.

Troin, M. and Caya, D., 2014. Evaluating the SWAT's snow hydrology over a Northern Quebec watershed. Hydrological Processes, 28(4), 18581873.

Van Liew, M.W., Veith, T.L., Bosch, D.D. and Arnold, J.G., 2007. Suitability of SWAT for the conservation effects assessment project: Comparison on USDA agricultural research service watersheds. Journal of Hydrologic Engineering, 12(2), 173-189.

Yalcin, E. and Tigrek, S., 2016. Hydropower production without sacrificing environment: A case study of Ilisu Dam and Hasankeyf. International Journal of Water Resources Development, 32(2), 247-266.

Yalcin, E., 2019. Estimation of irrigation return flow on monthly time resolution using SWAT model under limited data availability. Hydrological Sciences Journal, 64(13), 1588-1604.

Yang, X., Liu, Q., He, Y., Luo, X. and Zhang, X., 2016. Comparison of daily and sub-daily SWAT models for daily streamflow simulation in the Upper Huai River Basin of China. Stochastic Environmental Research and Risk Assessment, 30(3), 959-972.

Yolsu (Yolsu Mühendislik Hizmetleri Limited Şirketi), 2009. Başören HES Fizibilite Raporu. Yolsu Mühendislik Hizmetleri Limited Şirketi, Ankara, 162.
3- https://earthexplorer.usgs.gov/, (20.08.2019)

4- http://www.fao.org/geonetwork/srv/en/metadata.s how?id=14116, (20.08.2019)

5- http://forobs.jrc.ec.europa.eu/products/glc2000/pro ducts.php, (20.08.2019)

6- http://www.fao.org/soils-portal/soil-survey/soilmaps-and-databases/faounesco-soil-map-of-theworld/en/, (20.08.2019)

7- https://swat.tamu.edu/software/links/, (25.08.2019)

\section{internet Kaynakları}

1- http://www.dsi.gov.tr/faaliyetler/hessu-kullanimanlasmalari, (28.01.2020)

2- http://www.dsi.gov.tr/faaliyetler/akim-gozlemyilliklari, (19.08.2019) 